NBER WORKING PAPER SERIES

INTELLECTUAL PROPERTY RIGHTS AND ACCESS TO INNOVATION:
EVIDENCE FROM TRIPS

\author{
Margaret Kyle \\ Yi Qian \\ Working Paper 20799 \\ http://www.nber.org/papers/w20799
NATIONAL BUREAU OF ECONOMIC RESEARCH
1050 Massachusetts Avenue \\ Cambridge, MA 02138 \\ December 2014
}

We thank Tahir Amin, Iain Cockburn, Carsten Fink, Craig Garthwaite, Intan Hamdan-Livramento, Bhaven Sampat, Mark Schankerman, Tavneet Suri, and seminar participants at CERGE-EI, Copenhagen Business School, DIW Berlin, Duke, KU Leuven, Mannheim, MINES ParisTech, Northwestern, and the NBER Summer Institute, Peking University, Tsinghua University, the University of Hong Kong, andWIPO for useful comments and suggestions. Intan Hamdan-Livramento, Sumner LaCroix, andWalter Park generously shared their datasets on IPRs at the country level. Kyle thanks Pfizer for access to the IMS data used. The views expressed in this paper are entirely those of the authors, and we are responsible for all errors. The views expressed herein are those of the authors and do not necessarily reflect the views of the National Bureau of Economic Research.

NBER working papers are circulated for discussion and comment purposes. They have not been peerreviewed or been subject to the review by the NBER Board of Directors that accompanies official NBER publications.

(C) 2014 by Margaret Kyle and Yi Qian. All rights reserved. Short sections of text, not to exceed two paragraphs, may be quoted without explicit permission provided that full credit, including $\odot$ notice, is given to the source. 
Intellectual Property Rights and Access to Innovation: Evidence from TRIPS

Margaret Kyle and Yi Qian

NBER Working Paper No. 20799

December 2014

JEL No. I10,O34

\begin{abstract}
$\underline{\text { ABSTRACT }}$
We examine the effect of pharmaceutical patent protection on the speed of drug launch, price, and quantity in 60 countries from 2000-2013. The World Trade Organization required its member countries to implement a minimum level of patent protection within a specified time period as part of the TRIPS Agreement. However, members retained the right to impose price controls and to issue compulsory licenses under certain conditions. These countervailing policies were intended to reduce the potential static losses that result from reduced competition during the patent term. We take advantage of the fact that at the product level, selection into TRIPS "treatment" is exogenously determined by compliance deadlines that vary across countries. We find that patents have important consequences for access to new drugs: in the absence of a patent, launch is unlikely. That is, even when no patent barrier exists, generic entry may not occur. Conditional on launch, patented drugs have higher prices but higher sales as well. The price premium associated with patents is smaller in poorer countries. Price discrimination across countries has increased for drugs patented post-TRIPS and prices are negatively related to the burden of disease, suggesting that countervailing policies to offset expected price increases may have had the intended effects.
\end{abstract}

\author{
Margaret Kyle \\ MINES ParisTech (CERNA) \\ and PSL Research University \\ 60 boulevard Saint Michel \\ 75006 Paris \\ France \\ margaret.kyle@mines-paristech.fr \\ Yi Qian \\ Department of Marketing \\ Kellogg School of Management \\ Northwestern University \\ 2001 Sheridan Road \\ Evanston, IL 60208 \\ and NBER \\ yiqian@kellogg.northwestern.edu
}




\title{
Intellectual Property Rights and Access to Innovation: Evidence from TRIPS*
}

\author{
Margaret Kyle ${ }^{\dagger}$ and Yi Qian ${ }^{\ddagger}$
}

December 13, 2014

\begin{abstract}
We examine the effect of pharmaceutical patent protection on the speed of drug launch, price, and quantity in 60 countries from 2000-2013. The World Trade Organization required its member countries to implement a minimum level of patent protection within a specified time period as part of the TRIPS Agreement. However, members retained the right to impose price controls and to issue compulsory licenses under certain conditions. These countervailing policies were intended to reduce the potential static losses that result from reduced competition during the patent term. We take advantage of the fact that at the product level, selection into TRIPS "treatment" is exogenously determined by compliance deadlines that vary across countries. We find that patents have important consequences for access to new drugs: in the absence of a patent, launch is unlikely. That is, even when no patent barrier exists, generic entry may not occur. Conditional on launch, patented drugs have higher prices but higher sales as well. The price premium associated with patents is smaller in poorer countries. Price discrimination across countries has increased for drugs patented post-TRIPS and prices are negatively related to the burden of disease, suggesting that countervailing policies to offset expected price increases may have had the intended effects.
\end{abstract}

\section{Introduction}

Intellectual property rights (IPRs) attempt to balance static and dynamic efficiency. By allowing innovators to block competition and therefore appropriate a greater share of the value of their ideas,

${ }^{*}$ We thank Tahir Amin, Iain Cockburn, Carsten Fink, Craig Garthwaite, Intan Hamdan-Livramento, Bhaven Sampat, Mark Schankerman, Tavneet Suri, and seminar participants at CERGE-EI, Copenhagen Business School, DIW Berlin, Duke, KU Leuven, Mannheim, MINES ParisTech, Northwestern, and the NBER Summer Institute, Peking University, Tsinghua University, the University of Hong Kong, and WIPO for useful comments and suggestions. Intan Hamdan-Livramento, Sumner LaCroix, and Walter Park generously shared their datasets on IPRs at the country level. Kyle thanks Pfizer for access to the IMS data used. The views expressed in this paper are entirely those of the authors, and we are responsible for all errors.

${ }^{\dagger}$ MINES ParisTech (CERNA), PSL Research University and CEPR (margaret.kyle@mines-paristech.fr )

${ }^{\ddagger}$ Kellogg School of Management at Northwestern University and NBER (yiqian@northwestern.edu) 
IPRs can create incentives for investment in research and development (R\&D). However, IPRs can also lead to static inefficiencies in the form of monopoly prices. This tradeoff is especially acute in the case of pharmaceuticals for developing countries. Incentives for drug development are critical, since many diseases prevalent in developing countries lack appropriate treatments, but the prices of innovative drugs in the absence of generic competition make them unaffordable to most people there. The effects of IPRs on access and affordability are important for researchers, policymakers, and firms.

IPRs have expanded considerably in recent years as a consequence of the 1994 Trade-Related Intellectual Property Rights Agreement (TRIPS), negotiated at the end of the Uruguay Round of the General Agreement on Tariffs and Trade (GATT). TRIPS requires members of the World Trade Organization (WTO) to implement minimum standards for intellectual property (IP) protection. For most developing countries, complying with TRIPS involved substantial changes to their IPR policies, especially for pharmaceuticals. Supporters of TRIPS asserted that IPRs should benefit developing countries in several ways. First, IPRs create incentives for innovation that can benefit both rich and poor countries. Second, IPRs can promote domestic innovation in developing countries. And third, IPRs may increase the availability of new drugs, if innovative pharmaceutical companies find markets with IPRs more attractive for launch. The Office of the Trade Representative of the United States explicitly states that "Stronger patent and data protection increases the willingness of companies to release innovative drugs in free trade partners' markets, potentially increasing, rather than decreasing, the availability of medicines."'1 However, developing and least-developed countries have argued that patents reduce access to new drugs, since IPRs grant monopolistic positions to pharmaceutical companies and allow them to charge higher prices.

If IPRs make a market more attractive to innovators, either through increased pricing power or because they do not share the market with imitators, then we should increase product launches by innovator firms following a country's introduction of patents. In the presence of competitors, firms may fear creating spillover benefits for their rivals; a monopoly position would therefore increase investment in country-specific marketing and distribution channels. These investments may have implications for all products the firm sells within a country, regardless of their individual patent protection status. However, we should observe an effect on pricing only for those drugs eligible for patent protection in the country, i.e. those with a patent priority date post-TRIPS compliance. Higher prices would also be expected to reduce quantities sold.

Opponents of the TRIPS Agreement point to the substantial price differences often observed between innovator and generic products. HIV treatments are the most prominent example: competition from generic firms for the supply of antiretroviral drugs in developing countries has been credited with substantial reductions in price (Waning et al. (2010)).

This paper examines how IPRs, specifically patents, have affected new drug launches, prices

\footnotetext{
${ }^{1}$ http://www.ustr.gov/about-us/press-office/fact-sheets/archives/2004/july/us-morocco-free-trade-agreementaccess-medicine
} 
and sales across 59 countries of varying levels of development. We explain why patent protection may shift the equilibrium speed of launch, price and quantity. We then empirically examine these outcomes using data that allows us to compare patent protection in countries of different income levels. Though the introduction of IPRs is an endogenous decision taken by policy makers, developing countries were required by WTO rules to implement a minimum level of patent protection within a specified time period, and we argue that this requirement creates a natural experiment. In addition, we exploit the fact that these policy changes did not affect all drugs in the same way. Drug development has a large random component in the time between discovery (or initial patent date) and completion of clinical trials and regulatory requirements (or initial launch date). Within a country and year, we can compare the outcomes of products invented in a year before they were eligible for patent protection meeting all the TRIPS requirements with those invented just after TRIPS compliance. This allows us to control for unobservable country characteristics that affect an innovator's expected profitability and that vary over time, as well as unobservable product characteristics that affect price.

Our results suggest that the consequences of TRIPS-required patents on access have not been as negative as predicted by many in the global health community. Patents are generally associated with earlier launch of new products and higher sales. The effect of a patent on an innovator's launch incentive appears to be greater than the effect of removing this barrier to entry for generics, on average. This finding suggests the existence of other important barriers, some of which may be directly linked to regulatory policies. Surprisingly, we find a decrease in the price premium enjoyed

by drugs with patents in the post-TRIPS era, although patented drugs are nevertheless still more expensive. Countervailing policies such as price controls or the threat of compulsory licensing may be responsible, either directly or indirectly by inducing different pricing behavior from originators.

We summarize related literature in the next section, with a discussion of important institutional details and existing theory to motivate our empirical study. Section 3 explains our empirical model, and Section 4 describes the data. Results are presented in Section 5 , and we conclude in Section 6 .

\section{Background and literature}

\subsection{The impact of IPRs}

IPRs potentially have both static and dynamic effects. Standard theory models predict negative static effects, as patents allow inventors to block imitation. This monopoly position usually leads to higher prices and lower consumption. However, these static losses can be offset by increased incentives for inventors, leading to higher rates of innovation in the long run. There are some notable exceptions to these predictions, including Boldrin \& Levine (2002) and others who are critical of IPRs as a mechanism to induce innovation. We focus here on the empirical evidence, and specifically the pharmaceutical sector. 
A number of papers have examined the effect of IPRs on pharmaceutical innovation, an industry setting in which patents are especially important (Cohen et al. (2000)). In a study of 26 countries, Qian (2007) suggested that IP implementation increased domestic innovation only if accompanied by high levels of development, educational attainment, and economic freedom. Arora et al. (2008) found that patent applications associated with process innovations increased in India after its compliance with TRIPS in 2005. Lanjouw \& Cockburn (2001) investigated the impact of TRIPS on pharmaceutical innovations for diseases most prevalent in developing countries, but concluded that too little time had elapsed by the time of their study to observe large changes. Ten years later, Kyle \& McGahan (2012) examined whether TRIPS compliance stimulated R\&D activities for new drugs across the world. They found that TRIPS has strengthened research on global diseases that affect both high-income as well as developing countries, but it has not increased R\&D activities for diseases that almost exclusively affect low-income countries.

Other papers have focused on how IPRs have affected access to new treatments. In studies covering a large number of developed as well as developing countries, Lanjouw (2005) and Cockburn et al. (2014) found that stronger patent protection increased the speed of new drug launches in rich countries, but the effect in lower income countries was ambiguous. Borrell (2005), examining HIV treatments, found that patents were associated with faster launch in developing countries with relatively low levels of income inequality. However, the results of Berndt et al. (2011) suggest that while IPRs exist de jure, de facto protection in countries such as Brazil, India, and China remains weak. These countries generally see substantial entry by generic firms, conditional on launch by at least one firm.

The most important study in this area is Chaudhuri et al. (2006), who focused on a single category of antibiotics in India prior to the introduction of pharmaceutical product patents. Using counterfactual welfare calculations derived from structural estimation, they concluded that the introduction of IPRs would reduce social welfare, because of the increase in price a reduction in generic competition would cause both for new treatments and their older substitutes. In addition, domestic producers had an advantage in distribution, so that total consumption would fall substantially if the sole supplier was a foreign innovator firm. Given the importance of Indian generic firms in supplying low-cost treatments for HIV in developing countries (Waning et al. (2010)), the Chaudhuri et al. (2006) results have important implications for other countries as well. However, Duggan et al. (2014) find that product patents in India are not associated with large price increases between 2005 and 2008 .

\subsection{The TRIPS Agreement}

The TRIPS Agreement specifies the minimum levels and enforcement of IPRs, including patents, trademarks and copyright, that are a condition of membership in the World Trade Organization (WTO). TRIPS compliance requires patent terms of at least 20 years for products and processes. 
Two features of TRIPS are of particular importance here.

First, the introduction of product patents for pharmaceuticals was a major change for many countries. Product patents on pharmaceuticals allow the originator to protect the active chemical ingredient in a drug. This is considered the strongest form of protection, because no other firm can produce or import that chemical during the period of patent protection. LaCroix \& Liu (2008) note that in 1960, very few countries allowed pharmaceutical product patents, but more than $95 \%$ did so by 2005; TRIPS is responsible for much of this shift.

Second, the WTO established a process of dispute resolution between member states. If a country fails to comply with TRIPS, other member states may use this process to impose trade penalties on the offending country. To the extent that this gave patentholders (or at least their representatives in the governments of member states) greater enforcement power, we would expect TRIPS to strengthen patent protection in practice, even in the absence of a legislative change to patent law.

Developing and least-developed countries generally objected to some terms of TRIPS, and specifically to pharmaceutical product patents. To alleviate their concerns, poorer countries were permitted a transition period to comply with TRIPS. While developed countries had one year after joining the WTO to conform, most developing countries were required to implement TRIPS by 2000, and least-developed countries (LDCs) by 2006. However, countries that did not grant patents in a particular technology area in 1995 were given 10 years to comply. India, for instance, had until 2005 to introduce pharmaceutical product patents. The transition period for LDCs was later extended to 2016 for pharmaceutical product patents. Further details are provided in Section 4.3 .

Several other exemptions that weaken the strength of pharmaceutical patents were included in TRIPS to accommodate the concerns of developing countries as well as developed countries $\mathrm{L}^{2}$ The 2002 Doha Declaration first outlined the conditions under which countries may issue compulsory licenses; these conditions include limiting the use of the licensed product to the domestic market, restricting the use of compulsory licenses to cases of national health emergencies and providing "reasonable" compensation to the patent holder. Since many countries lack domestic manufacturing capacity and were therefore unable to use compulsory licenses, they negotiated the ability to import compulsory-licensed products from foreign markets (parallel imports) in 2003. Several countries have issued compulsory licenses, mainly for HIV treatments, although Thailand and India have also done so for other diseases such as hypertension and cancer. Several developed countries, including the United States, threatened compulsory licensing during public health scares such as flu outbreaks (Beall \& Kuhn (2012)).

Both developed and developing countries may impose price controls on pharmaceuticals under

\footnotetext{
${ }^{2}$ For example, the patent law of many developed countries includes a "Bolar provision," which permits research using a patented pharmaceutical during the term of patent protection if the purpose of the research is compliance with regulatory requirements for market approval.
} 
the TRIPS Agreement (discussed below). The combination of price controls and compulsory licensing (or the threat of either) may serve as an important check on the market power granted by pharmaceutical patents. These countervailing policies, which are challenging to account for in an empirical model, are critical for interpreting our results.

\section{$2.3 \quad$ Pharmaceutical regulation}

The pharmaceutical sector is highly regulated. Most countries require proof of safety and efficacy before permitting a drug to be sold, and many also regulate the prices that firms can charge for pharmaceuticals; see Scott Morton \& Kyle (2012) for an overview. Across developed and developing countries, there is variation in the regulation of market entry and in the use of price controls. Price controls may offset the expected effects of IPRs, since patent holders may be forced to charge lower prices (thus reducing the incentives for innovation) and access may be higher as a result (thus reducing the static inefficiencies associated with patents).

Most previous work on price regulation has focused on relatively rich markets. For example, Danzon et al. (2005), Kyle (2006), Kyle (2007) and Danzon \& Epstein (2008) all examine the relationship between price controls and the speed of access to new drugs. If country markets were completely independent and firms faced no capital constraints in product launch, we would expect firms to launch a new drug in all markets immediately, especially considering the limited term of patent protection (if applicable). In general, marginal costs of production are fairly low relative to the fixed cost of developing a drug, at least for small molecule drugs. So long as a firm can cover the marginal cost of producing the drug, the firm should be willing to sell. However, all these papers find that the reality is more complicated.

First, firms must incur country-specific entry costs. In countries such as the US and EU member states, the first firm to introduce a new chemical or biological entity must document the drug's safety and efficacy through clinical trial evidence. Most developing countries have regulatory agencies charged with granting marketing authorizations, though some allow firms to rely on dossiers provided to other countries. The process of price negotiation with particular governments can be time-consuming, generating further launch delays. This is a purely bureaucratic delay, although it may be increasing in regulators' preferences for low prices.

In addition, country markets are not truly independent. Many governments use "external reference pricing" when setting the local price, meaning that they base the local price on that observed in other countries. Thus, launching a new drug at a very low price in one country can reduce the price the firm receives in other countries, if initial low price is referenced. Country markets can also be linked through parallel trade, which is legal between European Union member states and has been considered by the US. Parallel trade amounts to arbitrage of price differences between countries, which again means that launch in a low-price market is less attractive than would be the case with independent country markets. The general finding from the literature cited 
above is that price controls are associated with launch delays. Whether the cost-savings generated by the use of price controls outweigh the delay in access is unresolved, as is the effect on dynamic incentives for investment in innovation.

With patent protection, the innovator may block entry by generic firms. Without patent protection, both innovators and generic firms are eligible to launch a new drug. Their incentives to do so depend on other policies, in particular regarding data exclusivity and the requirements for subsequent entrants. For example, many countries (including the US and EU member states) allow generic firms seeking regulatory approval to rely on the clinical data provided by the first entrant. They need only demonstrate that their product is bioequivalent to that of the first entrant's. The difference in regulatory treatment of first entrants and followers is considered vital for assuring generic competition, since it drastically lowers the entry costs for the latter ${ }^{3}$ However, the first entrant may be granted a period of data exclusivity over its clinical trial evidence, during which time generic firms must either independently provide similar evidence to the regulator or wait for its expiration. Even in the absence of a patent, therefore, potential entrants may not launch due to the high costs of acquiring clinical data for regulatory approval.

\subsection{Summary of theoretical predictions}

We assume firms (either innovators or generic producers) launch products when they expect positive expected profits. If subsequent entrants can rely on the clinical trial evidence of the first entrant and there is no period of data exclusivity, the first entrant may not be able to recoup the fixed costs of launch. With a period of data exclusivity, both the innovator and generic firms may be willing to launch. If it has already conducted clinical trials for regulatory approval in other countries, the innovator may have a cost advantage in doing so. With patent protection and no data exclusivity, then only the innovator has the right to launch the product. The innovator may choose not to launch because of the regulatory spillovers discussed above.

In the absence of price regulation, the theoretical effect of IPRs on price, conditional on launch, is fairly clear: the price with IPRs should be at least as high as that without IPRs 4 With price regulation, the theoretical effect is less obvious, and depends on regulators' willingness to reward innovators, attract entry, control expenditures, etc.

In the case of total quantity sold (conditional on launch and price), the expected effect of IPRs depends on the importance of country and product specific investments. Examples of such investments include educating medical professionals about the existence, use and benefits of a new drug; establishing distribution networks; ensuring the provision of complements such as diagnostics, etc. If competitors can free-ride on those investments, then generic competition in the absence of

\footnotetext{
${ }^{3}$ The 1984 Hatch-Waxman Act established the regulatory pathway for generic approval, after which generic entry increased substantially.

${ }^{4}$ An exception might occur if firms use price to signal quality when there are multiple producers of the same drug and no reliable government certification of quality.
} 
IPRs might result in lower levels of investment and lower quantities sold. On the other hand, generic firms may sell a larger portfolio of products than innovator firms and therefore have greater incentive to invest in distribution. In this case, removing generic firms from the market may reduce quantity sold via inferior distribution.

To summarize, the theoretical impact of IPRs on launch, price and quantity is ambiguous. Under regulatory conditions that require firms to provide clinical evidence of safety and efficacy (information that is a public good), IPRs are likely to result in faster launch. In markets with free pricing, IPRs are likely to result in higher prices; in markets with price controls, the effect may depend on relative bargaining power. For products that require substantial country-level investment in education and infrastructure, IPRs may encourage such investments and lead to higher quantities sold. Chaudhuri et al. (2006) suggest instead that generic producers have superior distribution, so that IPRs that block them from the market yield reduced quantities. Conditions may vary substantially across countries and products, so effects may be heterogeneous.

\section{$3 \quad$ Empirical model}

In this section, we describe our estimation methods for evaluating the effects of IPRs on the time to launch, price and quantity sold. We use data at the country-molecule-quarter level, which allows us to control for molecule and country effects and to use within-molecule, between-country and/or within-country, between-molecule comparisons in evaluating the effects of IPRs.

\subsection{Endogeneity of patent protection}

IPRs exist at the country level, and change for a subset of countries as a result of the TRIPS Agreement. One estimation of the effect of IPRs is a comparison of the overall launch speed, price level and quantity sold within countries following the introduction of IPRs, compared with those that did not. If adoption of IPRs is driven by time-varying unobservables, however, this differencein-difference will yield biased results. Cockburn et al. (2014) use instrumental variables such as legal origin, ethno-linguistic fractionalization, and the number of bilateral trade agreements signed by a country in their study of drug launches.

Developing countries generally opposed the requirements of TRIPS, so one could argue that this policy was exogenously imposed on many of them (Hamdan-Livramento (2009), LaCroix \& Liu (2008)). At the time of the WTO's establishment, member countries that declared themselves as "developed" had one year to bring their IPRs up to the minimum standards specified by TRIPS. Developed countries that joined after 1995 were required to be compliant at the date their WTO membership began. Original WTO members that declared themselves as "developing" were permitted a transition period for TRIPS implementation, with a deadline of 2000. A longer transition period, until 2005, was permitted for countries that did not grant pharmaceutical product patents, 
such as India. These countries were required to provide a "mailbox provision" until then, i.e. accept patent applications even while deferring decisions until 2005, and to grant applicants five years of marketing exclusivity during the transition period. 5 Least- developed countries, designated as such by the United Nations, had the longest transition period: initially the deadline was January 1, 2006, and this was extended to 2016 as a result of the Doha round of negotiations in 2002. That said, some countries resisted more than others, and some complied early. An instrument for the year of actual compliance is the year by which a country was required to implement TRIPS under WTO rules. One possible instrument for IPRs at the country-year level is the WTO's deadline for TRIPS compliance. However, it is correlated with the level of development, and has only crosscountry variation. The decision by originators to seek patent protection on a particular molecule where and when such protection is available is also potentially endogenous. If originators perceive patent protection to be ineffective or do not expect to market due to low profit expectations, they may not even submit applications for patent protection.

We adopt an approach that exploits our country-molecule-quarter level information on patents. Following changes to patent law in accordance with TRIPS, only a subset of products within a country qualifies for strengthened patent protection and any associated pricing power, and this subset is exogenously determined by the priority date of the first patent application globally and the country's required compliance dates with TRIPS. Similarly, within a molecule, the countries in which a drug qualifies for product patents is exogenously determined by the date its priority patent application was filed. We therefore define a "Post-TRIPS treated" group of products within a country, composed of molecules whose patent priority dates allows them to apply for a patent under a TRIPS-compliant legal regime in a country. If the patent priority date determining whether a product qualifies for a Post-TRIPS patent in a country is exogenous, then the difference in outcomes between products with pre-TRIPS patents and those with Post-TRIPS patents captures the effect of strengthened IPRs ${ }^{6}$ Within a country, the expiration of a granted patent is exogenously determined by its application date, although patent extensions may apply in some cases.

We estimate separate regressions for each of our dependent variables of interest, i.e. the speed of launch, price, and quantity sold. With this approach, we are assuming that firms first choose whether (and how quickly) to launch, which may depend on the existence of IPRs. Given launch, we examine whether prices are higher in the presence of IPRs and whether the quantity sold changes in the presence of IPRs. To be clear, we are not estimating structural demand and supply equations. Our claim is only that IPRs may shift the equilibrium levels of these outcomes.

We use a discrete-time model of firms' launch decisions, assuming that we observe launch if firms expect positive profits from market entry. The latent variable for profit $\Pi_{i j t}$ denotes the profit from the launch of $\operatorname{drug} j$ in country $i$ and in quarter $t$, and we specify the following reduced-form profit

\footnotetext{
${ }^{5}$ The US challenged India's compliance with these terms in a WTO trade dispute.

${ }^{6}$ In many countries, a patent system existed prior to official TRIPS compliance, but may not have offered the same level of protection.
} 
function conditional on drug launch:

$$
\begin{aligned}
\Pi_{i j t} & =\alpha_{0}+\alpha_{1} \text { ExpiredPatent }_{i j t} \\
& +\alpha_{2} \text { OnPatent }_{i j t} \\
& +X_{i j t} \mu+\tau_{i t}+\psi_{j}+\epsilon_{i j t}
\end{aligned}
$$

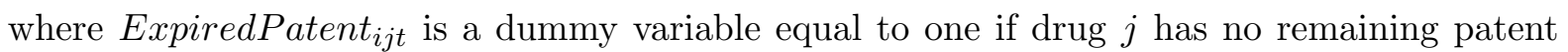

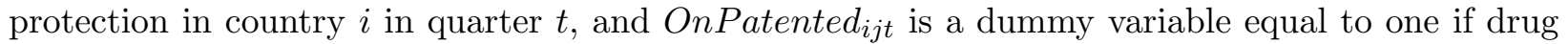
$j$ has an active patent (i.e., granted and not yet expired) in quarter $t$. The omitted category is the case of a drug that was never patented in country $i . X_{i j t}$ is a vector of other variables that may affect the launch probability (market size, GDP levels, the number of previously launched substitute pharmaceutical treatments for $\operatorname{drug} j$ in country $i$, etc.), $\tau_{i t}$ is the time elapsed since the first international launch for $\operatorname{drug} j$ in country $i$ at time $t, \psi_{i}$ is the disease category fixed-effect 7 and $\epsilon_{i j t}$ is the unobserved error term. We estimate this using a discrete-time hazard with a logit link.

The theoretical effect of IPRs is ambiguous in the launch equation. We simply estimate whether countries have earlier access to innovations when patent protection exists (or ever existed) there, without distinguishing whether the originator or imitators enter first. Originators may be more likely to launch when they have strong IPR protection, but international reference pricing may cause strategic delays in the launch. Generics may be quicker to market if no IPRs exist, but if they rely on entry by an originator to reduce their regulatory requirements, they may not necessarily enter the market before the originator.

We next examine the relationship between IPRs and price by estimating the following equation, conditional on launch:

$$
\begin{aligned}
P_{i j t} & =\beta_{0}+\beta_{1} \text { ExpiredPatent }_{i j t} \\
& +\beta_{2} \text { OnPatent }{ }_{i j t} \\
& +X_{i j t} \nu+\phi_{j}+\epsilon_{i j t}
\end{aligned}
$$

where $\phi_{j}$ is a drug fixed-effect and other variables are defined as in the launch model. The drug fixed-effect controls for unobserved quality. Generally, we expect IPRs to give originators some market power, and for this to be reflected in higher prices on patented products. However, the use of price controls by countries may limit those price increases.

Finally, we turn to quantity. It is possible that originators may be more willing to undertake

\footnotetext{
${ }^{7}$ We chose to use disease fixed-effects rather than drug due to the computational burden of estimating more than 700 fixed-effects in a non-linear model.
} 
investments in education and advertising if they are able to appropriate most of the benefits, which is more likely in the absence of generic competition. However, originators may invest less in distribution, since they may have a smaller product portfolio than generic firms. To evaluate the effect of IPRs, we estimate the following equation:

$$
\begin{aligned}
Q_{i j t} & =\gamma_{0}+\gamma_{1} \text { ExpiredPatent }_{i j t} \\
& +\gamma_{2} \text { OnPatent }_{i j t} \\
& +X_{i j t} \mu+\phi_{j}+\epsilon_{i j t}
\end{aligned}
$$

where variables are defined as earlier.

We next estimate specifications that allow for the effect of patents to vary across countries. First, we interact our patent status variables with country income per capita (logged). As an alternative, we interact patent status with World Bank income group definitions to examine differences between different levels of development. We also include a specification in which we allow for the effect of patents to vary by country, rather than by income group.

Finally, we distinguish between pre- and post-TRIPS patents. Instead of defining a dummy variable for whether a drug is currently on patent, we define whether it is protected by only preTRIPS patents or has some patent protection under a country's TRIPS regime. We again allow this to vary by country income groups. This specification allows us to explore the effects of TRIPS in particular, rather than patents generally.

We perform the analysis using the two definitions for "patented": the existence of any patent (product, process, etc.) and the existence of a product patent. While product patents have received the most attention and were the most contentious legislative change, researchers and policymakers have also focused on the use of follow-on patents to extend market exclusivity. The latter specifications provide some insight into whether such additional patents affect originator incentives to launch and market their products.

We also estimate the equations above with the addition of a country fixed effect, $\delta_{i}$. This fixed-effect will absorb differences across countries in, for example, the efficiency of bureaucracies in approving new drugs; policies on price controls and reimbursement; and enforcement. The difference between pre- and post-TRIPS patents is therefore a comparison of two groups of products, one treated by theoretically stronger protection, net of unobserved quality differences (which are absorbed by drug fixed-effects).

\subsection{Instrumental variables approach}

A limitation of the above approach is that patent protection is the endogenous outcome of decisions by two key players. First, the originator must apply for protection (if offered in a country), and 
expectations about the state of future patent protection in a country, or effective enforcement, as well as expected price and quantity will influence this decision. Second, the policymaker or patent office must grant the patent. As discussed above, many countries did not offer patent protection, or offered weaker forms of protection, prior to TRIPS.

In an alternative model, we define an indicator variable for whether a drug was eligible for TRIPS-compliant patent protection in a particular country, i.e. TRIPS compliance occurred no later than the priority date plus 30 months. Having a priority date within this window exogenously shifts the incentive for originators to apply for a patent (because of stronger protection or enforcement) and the obligation of patent offices to grant pharmaceutical product patents. In addition, patents have a predetermined maximum term. While other country policies may extend this, we take the "normal" expiration date of the first patent on a drug within a country as exogenous, at least at the level of a specific patent at the time of filing. These patent terms vary across countries and over time, as laws were changed to comply with TRIPS. For example, in 1995, the maximum term of patent protection in the US changed from 17 years from the grant date to 20 years from the filing date. We use indicators for the priority date falling within the period of TRIPS eligibility and for the current period falling within the standard patent term following the approach recommended by Wooldridge (2010).

First, we estimate a reduced-form model of patent protection (which we will call "stage 0"):

$$
\begin{aligned}
\text { PatentedDrug }_{i j t} & =\nu_{0}+\nu_{1} \text { WithinWindow }_{i j} \\
& +\nu_{2} \text { WithinTerm }_{i j t} \\
& +X_{i j t} \kappa+\phi_{j}+\xi_{i j t}
\end{aligned}
$$

We then calculate predicted values PatentêdDrug $g_{i j t}$, and use this and its interaction with other variables as instruments in the second stage regressions of price and quantity:

$$
\begin{aligned}
P_{i j t} & =\rho_{0}+\rho_{1} \text { PatentedDrug }_{i j t} \\
& +\rho_{3} \text { IncomeGroup }_{i} * \text { PatentedDrug }_{i j t} \\
& +X_{i j t} \chi+\phi_{j}+\epsilon_{i j t}, \\
Q_{i j t} & =\gamma_{0}+\gamma_{1} \text { PatentedDrug }_{i j t} \\
& +\gamma_{3} \text { IncomeGroup }_{i} * \text { PatentedDrug }_{i j t} \\
& +X_{i j t} \omega+\phi_{j}+\epsilon_{i j t},
\end{aligned}
$$


where PatentedDrug Pijt $_{\text {and IncomeGroup }} *$ PatentedDrug $_{i j t}$ are instrumented using the predicted values from stage 0 , the square of predicted values, and the interaction with income (GDP per capita, logged). As above, we also estimate an alternative specification using World Bank income groups rather than a continuous measure of income. Although the dependent variable in stage 0 is discrete, we use OLS due to the large number of fixed-effects. This method is robust to misspecification of stage 0 , although the estimator is not efficient if the linear probability model we use is not correct.

The main drawbacks to this approach are the following. Since we lack separate instruments for pre- and post-TRIPS patents, we treat any patent protection as the endogenous treatment variable. The omitted category, no patent protection, includes both drugs that were never patented and those with expired patents. Treatment effects are likely to be heterogeneous if patent protection has different effects across countries and/or drugs. Finally, we cannot implement an instrumental variables estimator for the nonlinear model of launch.

\section{Data}

\subsection{Market outcome data}

Our data on key market outcomes of interest - the speed of launch, price, and units sold - comes from the MIDAS dataset produced by IMS Health. We have quarterly data on prices and units sold from 2000-2013 and on launch from 1990-2013, a time period that allows us to examine several years pre- and post-TRIPS implementation for many developing countries. The original data is provided at the package level, i.e. bottles of $3010 \mathrm{mg}$ tablets. For drugs sold in multiple packages and presentations, we aggregate the revenues and number of "standard units" (smallest dose) up to the level of a molecule or combination. Although there is some price discrimination across packages within a country, this aggregation facilitates comparisons across countries. Each drug is assigned to a therapeutic class (at the ATC3 level); for drugs with sales in multiple classes, we use the class with the highest level of sales as its primary disease market.

The IMS data includes a total of 33,240 unique molecules or combinations of molecules, many of which are quite old. We exclude diagnostic agents (ATC class T) and drugs that cannot be easily assigned to a disease (ATC class V). We focus on drugs first launched anywhere in the world after 1990, since it is this set for which TRIPS is most relevant. Drugs that are unique to one country, a set that includes many homeopathic products in India and China, are dropped from our analysis. Finally, we restrict our sample to drugs that we could match to patent information. This leaves us with a total of 716 drugs.

For each molecule-country pair, we observe launch date, the total sales in nominal local currency, and the number of units sold. We convert nominal sales to real values using the country's GDP 
deflator. We calculate price as total sales divided by the total number of standard units sold 8 Thus, within-country price changes do not reflect exchange rate fluctuations or inflation. For crosscountry comparisons, we express prices in constant US dollars using the average exchange rate for $2013 \mathrm{Q} 4$.

We keep one observation per country and quarter for each drug starting from its initial launch. A drug is considered launched in a country once positive sales are observed; prior to its launch in a country but following its first launch elsewhere, launch is coded as zero and price and sales are coded as missing. Ultimately, this dataset includes 56 quarters, 60 countries, and 716 unique molecules, amounting to 1459993 molecule-country-quarter observations.

\subsection{Firm-level data}

We distinguish between originators, or firms that invest in the development of a new drug, and generic firms. Originators generally own patent rights on the molecule or a license to those rights. Many drugs are developed and/or marketed under license by multiple firms. For example, several firms could collaborate in the development, with one firm responsible for marketing the drug globally, or one firm might develop the drug and license it out to other firms for marketing in North America, Europe, etc. We use two approaches to identify these firms. First, the MIDAS dataset includes some information on the licensing status of each firm generating sales of a molecule in a country. If the licensing status is available and listed as either "original brand" or "licensed brand", we treat the observation as an originator sale, since the originator receives some payment for the sale of a licensed brand or at least authorized its sale. For the remaining cases, we use the R\&D Focus database provided by IMS Health, which tracks drug development projects and includes information on the drug, its intended uses, and the firms participating in its development or marketing. We designate any firm listed as a co-developer or licensee on a drug project that is also selling the product in one of our sample countries as an originator. All other sellers of that drug are coded as generic firms or parallel importers 9

\subsection{Country-level data}

Summary information for the countries in our sample, including the dates of TRIPS deadlines, World Bank income group definitions in 2000 and 2013, and region, is provided in Table 1. Our sample includes the major emerging markets of Brazil, Russia, India, and China, as well as Indonesia, Malaysia, Thailand, and South Africa. Thirty of our sample countries had TRIPS compliance dates in 2000 or later (see Table 1). Many countries had adopted pharmaceutical product patent

\footnotetext{
${ }^{8}$ Some observations have negative values for sales, which reflect the return of products to the manufacturer. We set price to missing in these cases.

${ }^{9}$ Parallel importers sell the originator's own products in a country, but without a license. Parallel trade is widespread within the European Union and is thought to be important in some developing countries. We are only able to identify parallel traders within Europe, however.
} 
legislation prior to their official compliance deadlines. Quite a few rose in income classification between 2000 and 2013. In our analysis, we use the income classification as of 2000. Results are similar using the 2013 definition, although we have fewer countries in the lowest income group.

Our main focus in this paper is the effect of IPRs on the outcomes in country-markets, so it is critical that we correctly measure the existence or strength of IPRs at the country-level over time. There are a number of possible candidates. The first is the Ginarte-Park index of IPRs and enforcement (Ginarte \& Park (1997)). This measure has the advantage of including a specific index of patent protection for chemicals. It is only available at 5-year intervals, however, and is not available for every country in our sample. We complement this with information collected by LaCroix \& Liu (2014) and Hamdan-Livramento (2009). We thank these authors for their willingness to share their datasets.

An additional form of protection available in many countries is called data exclusivity. During the period of data exclusivity, only the owner of the data may use it to obtain regulatory approval for marketing a drug. This varies across countries and over time. Based on country $i$ 's data exclusivity term at time $t$, we define a dummy variable equal to one if drug $j$ was likely to be protected by data exclusivity.

To control for the impact of economic development or income level, we use the World Development Index (WDI) dataset from the World Bank. It includes GDP per capita, population, the Gini coefficient of income inequality, health expenditures per capita, life expectancy, out-of-pocket health expenditures, poverty rates, and GDP deflators across the sampled countries. To retain as much of our sample as possible, we include only the subset of WDI indicators with very complete coverage. Our source of information on quarterly exchange rates between the local currency and the US dollar is the Pacific Exchange Rate Service for most countries, and individual central banks otherwise.

\subsection{Disease data}

We define a market as a country-disease pair. Regulatory approval is required at the country level in order to market a drug, and gaining regulatory approval in one country does not generally allow a firm to access other countries 10 In addition, demand for a drug that treats a particular disease is generally limited to the population affected by that disease. For example, we would not expect demand for a colon cancer drug to be very high among those who do not have colon cancer. Since the burden of disease (or demand) can change over time for any number of reasons (aging of the population, spread of infectious diseases, changes in risky behaviors, etc.), our ideal measure would capture such changes.

\footnotetext{
${ }^{10}$ Within the European Union, a firm can use a centralized approval process handled by the European Medicines Agency to win approval among all member states. Alternatively, a firm can apply for regulatory approval in one member state and use this member state as a reference for approval in other EU countries. However, in order to have the product reimbursed, the firm must negotiate with different (country specific) regulators over the price.
} 
One approach, used by Danzon et al. (2005) among others, is the lag of total sales in each therapeutic class-country. A disadvantage of this measure is that it reflects demand for older products, rather than potential market size. This is especially problematic where previous treatments were unavailable or inadequate: the sales of HIV treatments in 1990 would be a massive underestimate of the potential market size. A new drug that represents a major therapeutic advance would expect to sell to the previously untreated population. In addition, historical sales of unpatented drugs with aggressive price competition may not be an accurate forecast of the potential market for a new treatment with patent protection.

The second measure is the number of deaths due to a disease from the WHO's mortality data, which has the advantage of covering most countries at annual intervals. This measure of disease burden has several limitations, however. Coverage of poorer countries is incomplete, and likely to include significant measurement error; the WHO cautions against making cross-country comparisons since there are differences in how deaths are recorded across countries. In addition, mortality is not the preferred measure of disease burden. For example, hypertension or diabetes might increase the probability of death, but may not be recorded as the direct causes of death. The mortality measure tends to underestimate the true burden of many chronic diseases that take a long time to kill, but that take a toll during the affected person's lifetime.

A third measure of disease burden is known as "disability-adjusted life years," or DALYs. This measure is also available from the WHO, but only for a single cross-section of countries in 2004. For diseases with considerable variation over time, such as HIV, this will again introduce measurement error. However, it is considered more appropriate for cross-country comparisons than mortality. We matched each drug's ATC classification to its DALY code, using fairly aggregate disease definitions (e.g., infectious and parasitic diseases are matched to ATC codes J and P) 11

Finally, we can allow for each country to have a specific disease effect by including country-ATC fixed-effects. This avoids any issues in matching ATC codes to disease-level information from other sources. However, it does require us to assume that the relative importance of diseases within a country is stable during our study period, and increases the number of parameters substantially. We estimate these models as a robustness check, but focus on more parsimonious specifications.

\subsection{Patent data}

Information on patents comes from IMS R\&D Focus and Patent Focus, which we match to the MIDAS data described above using the generic or chemical name. Of the 2,369 drugs that R\&D Focus identifies as launched after 1990, we were able to identify patents for 716 . The unmatched drugs are usually new versions or combinations of old molecules, for which originators rely on country-specific data exclusivity protection in lieu of patents. The two data sources do not use common identifiers. Where possible, we matched on chemical or molecule names. For vaccines and

\footnotetext{
${ }^{11}$ see http://www . who.int/entity/healthinfo/statistics/gbdestimatescauselist.pdf
} 
patents on drug delivery technologies, and for patents identified only by the name of the branded product, additional work is required to find the corresponding product in the other dataset.

There are a number of complications in using pharmaceutical patent data. Linking patents to marketed drugs is a many-to-many match. Most molecules have multiple associated patents, covering the molecule itself, a use of the molecule, manufacturing processes, etc. In addition, a single patent may protect multiple drugs. For example, the HIV treatment markted as EPZICOM in the United States is a combination of abacavir (sold under the brand name ZIAGEN) and lamivudine (sold as EPIVIR). Patents protecting one of the individual molecules may block entry into the combination product, and there is also a patent on the combination. A process patent for the preparation of optically active cis-nucleosides that specifically mentions abacavir and lamivudine could protect each of the single-molecule products. Despite a move towards harmonization of IP laws, the same molecule might be eligible for a different number of patents in different countries, or different breadth of coverage.

When a molecule is protected by multiple patents, it is not always straightforward to determine which patent is most important for blocking competition; this is true not only for the econometrician, but also for patent attorneys and the managers of pharmaceutical firms. Generic competition may legally occur despite the existence of a patent on a molecule, because the patent covers a manufacturing process that generics have worked around, or because the originator has authorized a generic. In some countries, generic competition may also occur because no patent exists, or because patents are not enforced. We use two different measures of patent protection in the empirical analysis: the existence of an active patent (post-grant date and pre-expiration date) and the existence of an active product patent, which is considered the most difficult to invent around.

We use the first application date for any patent associated with a molecule across all countries as an approximation of its priority date ${ }^{12}$ Originators generally must apply for protection in other countries within 12-30 months of the priority date. Under the Paris Convention, inventors have 12 months to apply in other countries. Under the Patent Cooperation Treaty, inventors may take an additional 18 months, for a total of 30. We account for each country's status as a signatory to the PCT in variable definitions. Because of the lengthy period of clinical trials, the priority date of the first patent is usually at least 5 years before the launch date of a new drug.

We observe patenting activity in many countries prior to their required compliance with the TRIPS Agreement. Some complied early, and most maintained a pre-TRIPS patent system that provided weaker protection than TRIPS required. In addition, the legal availability of patents may not always lead to the use of patents. If a market is very small or cannot support prices that allow the firm to recover variable costs and the fixed costs of launch, then a firm may not bother to apply for a local patent. Similarly, we may not observe patent applications when a firm expects

\footnotetext{
${ }^{12}$ The filing date and priority date can be different, particularly when a patent application is derived from a parent application. We do our best to deal with this by selecting the earliest filing date for all patents associated with a molecule.
} 
lax enforcement of the patent or a negative decision from the patent office.

We define a drug $j$ as "on patent" in country $i$ in quarter $t$ if quarter $t$ follows the earliest grant date of any patent on $j$ in $i$ and if quarter $t$ precedes the last expiration date of any patent granted on $j$ in $i$. Pre-TRIPS, the patent term varied by country. Post-TRIPS, patents have a duration of 20 years from the date of application. In some countries, drugs may be protected by "supplementary protection certificates" or patent term extensions that allow years of market exclusivity. We adjust our definition of "on patent" for patent extensions, lapsed patents, and invalidated patents. For the specifications that focus on product patents, we use analogous definitions but exclude process, composition, and other types of patents.

\subsection{Summary of data}

The distribution of broad disease areas for the molecules in our regression sample is listed in Table 2. Cancer, cardiovascular treatments, and anti-infectives have the highest number of molecules. The list of countries included, along with their required TRIPS compliance dates and dates of pharmaceutical product patent legislation, is contained in Table A of the appendix. For ease of explication, we combine the three low income countries (India, Indonesia and Pakistan) with the lower middle income group in the discussion and analysis that follows. All three were considered lower middle income by 2013.

There is wide variation across countries in the fraction of drugs with product patents. For example, there are very few with product patents in the United Arab Emirates and the Dominican Republic, but more than $70 \%$ of the drugs launched since 1990 in the United States had a product patent. Even among high income countries, some introduced product patent legislation relatively late (such as Norway, Spain, and Estonia) and have a lower share of drugs with product patents. Those without product patents in the US are generally older drugs for which a new use has been discovered, or combinations of drugs that may not always qualify for product patents. The share of products for which originators beat generics to market also varies substantially. The originator is first more than $80 \%$ of the time in most countries. However, India is a clear exception: originators are first in fewer than $20 \%$ of the opportunities (see Table A). In some South American and Middle Eastern countries, generic firms precede originators in a significant number of cases. Some of these countries only recently implemented product patents, but others may have weak patent enforcement. Overall, the pattern of launch suggests that generic firms often rely on local entry by originators, perhaps because obtaining regulatory approval is easier once the originator has provided clinical data or because originators invest in advertising that generic firms can benefit from. It also underscores the importance of patents in India compared with other developing countries. The impact of introducing patent protection is likely to be larger in India than anywhere else, and may have consequences for the supply of generic drugs to countries where IPRs do not block entry.

Table 3 presents simple means of several key variables by income group and patent status. Not 
surprisingly, the fraction of product launched is generally increasing in country income, with $55 \%$ of eligible treatments available at some point during 1990-2013 in high income OECD countries, but only $35 \%$ for lower middle income/low income countries. Launch by originators is faster in high income countries, and originators are quicker to markets than generics in every income group. However, generic entry is more likely in the upper and lower middle income groups, and occurs slightly earlier than in high income countries on average 13 The existence of a product patent implies faster originator entry (a median of 1.5 versus 3.51 years). More surprisingly, generic entry is slow whether a product patent exists or not, though somewhat more likely when no product patent exists. However, originators are still first in more than three-quarters of the cases. This suggests that product patents are not the only important barrier to entry in most countries. Figure 1 shows the distribution of the number of producers over drug-country-quarter observations by patent status; results using the presence of any patent are similar. The presence of a product patent mostly affects whether any producer is active. That is, there is a shift from no producers to a monopoly; the shift from more competitive markets to a monopoly is not evident. Of course, originators are more likely to seek patents where they expect to earn positive profits. These simple summary statistics suggest that if originators do not expect profits, generic firms may not either.

Trends in patenting and launch activity are shown in Table 4 . There is a clear increase in patenting over time (subject to truncation issues for recently introduced drugs, for which secondary patents may continue to be granted). Launch lags remain significant: while drugs first launched since 1995 appear to be reaching more countries than those pre-1995, those first launched since 2005 have not yet reached half the countries in our sample.

Summary statistics for variables used in the regression analysis are presented in Tables 5 and 6. Table 5 contains the sample used for the launch regression, which runs from 1990-2013; only observations up to and including the quarter of launch are included for this analysis. Table 6 corresponds to the sample used for the price and quantity regressions, for which data is available from 2000-2013. Only observations post-launch are included.

\section{$5 \quad$ Results}

\subsection{Main effects}

In all the tables of estimation results that follow, standard errors are clustered by country. Year fixed-effects are included in all specifications, drug fixed-effects are included in the price and quantity regressions, and therapeutic-class fixed-effects are included in the launch regressions. Because our price measure is the price per "standard unit," which varies across drugs ${ }^{14}$ it is essential that we include a drug fixed-effect. This inclusion is also important if patents are more likely to be

\footnotetext{
${ }^{13}$ The different outcomes observed in the high income non-OECD category likely reflect the small number of countries (Kuwait, Singapore, Slovenia and the United Arab Emirates) with high income inequality.

${ }^{14}$ Ideally, we would use the price per standard course of treatment, but this is not available.
} 
granted on novel drugs and novelty is positively correlated with a drug's quality or effectiveness, or if originators are more likely to seek protection on high quality drugs (though quality is generally difficult to assess when the first patent applications are filed).

Market size is approximated by country level variables such as the disease burden associated with each drug's primary therapeutic class, population, GDP per capita and life expectancy. Information on national health policies such as the existence of an essential medicines list, use of price controls, average out-of-pocket expenditures, etc. is available for a subset of countries, and the effect of many of these (endogenous) policies on access is, of course, also of great interest. However, incorporating this information would reduce the sample of countries considerably. Because we observe few changes for these policies over time within countries, we instead include a country fixed-effect in some specifications. Other control variables include the number of substitute drugs sold locally and the number of products marketed by the originator in country $j$ (both lagged one period). Finally, a lagged price index that tracks changes in the price of other (older) drugs in the same ATC3 therapeutic class is included. Our discussion below focuses only on the variables related to intellectual property.

Tables 7 and 8 present the results of the simplest specifications we estimate. We exclude country fixed-effects, and focus only on how the existence of a patent affects launch, price and quantity sold. We distinguish between cases where no patent ever existed (the excluded category), where a drug had some patent protection that has expired, and where a drug is currently protected by a product patent (Table 7) or any patent (Table 8). On-patent products are most likely to be launched and to sell in higher quantities, but also command the highest prices. Products with expired patents sell in lower quantities and at lower prices than those that are on patent, but higher prices and quantities relative to those that were never protected. The latter likely reflects the greater availability of patent protection in richer countries and the greater incentives to seek patents in those markets.

Tables 9 and 10 include country fixed-effects. These absorb time-invariant differences in regulatory barriers, the structure of retail and hospital pharmacy distribution, price controls, and other factors. While the results for product launch are very similar, we find much smaller coefficients on patent status in the price and quantity regressions. This is not very surprising, since richer countries generally granted patents earlier than poorer countries and incentives to patent in rich countries are also probably higher. The price variation associated with patents appears to be driven mostly by cross-country variation.

\subsection{Effects by country income}

We next explore whether the importance of patents varies by country income. Demand for pharma-

ceuticals in rich countries tends to be somewhat inelastic, especially when patients have insurance coverage. In contrast, the average patient in a poorer country may be unable to pay high out-ofpocket prices or to afford insurance, limiting the ability of originators to exercise any market power 
provided by patents. We would therefore expect prices to be lower overall in poorer countries, and for the patent premium to be smaller there. That said, there are reasons to expect deviations from this pricing pattern. If firms are unable to price discriminate across patients of different income levels within a country, they may choose to set a high price and sell only to the richest segment in lower income countries. Governments in rich countries may act as monopsony purchasers or have greater bargaining power in negotiating prices with pharmaceutical firms than poorer countries. Both factors suggest that prices may be relatively high in poorer countries, with lower quantities sold.

Results from regression specifications that interact patent status with logged GDP per capita are presented in Tables 11 and 12. We find the most striking differences for launch. Drugs that are never patented are unlikely to be marketed, regardless of income. Launch of on-patent drugs is increasing in income, but the opposite is true for drugs with expired patents. In other words, poor countries are more likely to receive older drugs (meaning they could be sold either by originators or by generic firms, although we showed earlier that originators are more likely to be first); firms are less likely to introduce drugs with expired patents in rich countries. Clearly, selection is important. Drugs that prove unsuccessful in their initial launch markets may never be sold globally. The results for price also suggest that patents are indeed worth more in richer markets, although differences between never patented, expired patent and on-patent products are not statistically significant. That is, differential pricing across countries is not markedly different for on-patent drugs, which is somewhat surprising. If markets were perfectly competitive in the absence of a patent barrier, we would expect price to fall to marginal cost and to vary little across countries. In fact, we observe large price differences across countries regardless of patent status. In the case of quantity, the estimated difference across patent status is an imprecisely estimated zero. Results using World Bank income group classifications, shown in Tables 13 and 14, are very similar.

Next, we explore whether TRIPS changed the value of patents. In Tables 15 and 16 , we allow the effect of patents to vary by income group and distinguish between patents granted pre-TRIPS or post-TRIPS. As described earlier, the same drug can have pre-TRIPS and post-TRIPS patent status in two different countries, depending on when each complied with TRIPS. Within a country, we argue that the set of drugs with post-TRIPS patents is also (mostly) exogenously determined by priority dates and TRIPS deadlines. Figures 2 , 3 and 4 provide a graphical summary. Overall, drugs are more likely to be launched if they have post-TRIPS patents, as well as to sell in higher quantities. The most surprising result is that the price of such drugs is lower than pre-TRIPS patented products, on average, in the poorest category of countries.

We interpret these results with caution, since they are driven by a small number of drugs. Most low and lower middle income countries faced TRIPS compliance deadlines of 2005. Because of the lengthy drug development cycle, very few drugs first patented after 2005 have been brought to market by 2013, when our sample ends. Identifying differences is difficult once drug fixed effects are 
included, and our estimates are noisy. However, the general pattern that emerges is that prices have not significantly increased post-TRIPS, and quantities have not significantly declined, in relatively poor countries. We discuss possible explanations in section 5.4. In addition, while we include drug fixed-effects to control for the quality of a molecule, it is also possible that quality varies between manufacturers of the same molecule. In recent studies of the quality of drugs available in pharmacies in the developing world, Bate et al. (2014a) and Bate et al. (2014b) present evidence of significant quality differences between manufacturers and countries. They find that innovator products tend to be of higher quality. Thus, higher prices on innovator products may signal quality in markets where less stringent regulation exists. In the absence of generic competitors, originators may have less reason to signal quality through price.

\subsection{Results using instrumental variables}

Our final analysis adopts a different approach to identifying the effect of patent protection. Rather than grouping products by whether they have pre- or post-TRIPS patents, we use a country's compliance with TRIPS as an exogenous shifter for the incentives of firms to seek patents and for a country to grant them. We can also exploit the exogenously determined (at the time of patent application) statutory patent term, which should be correlated with patent status but have no effect on price or quantity except through patent status. The statutory limit should be unrelated to quality, unlike patent term extensions or other regulatory provisions for market exclusivity. It should also be unrelated to endogenous challenges (which are more likely for expensive or important drugs) to a patent's validity. The statutory patent term is specified by law as years since application or years since grant. Since the decision to apply (and possibly to grant) is endogenous, we instead base this definition on the priority date plus 12 or 30 months, depending on a country's status as a signatory to the Patent Convention Treaty. As noted above, we focus only on the linear price and quantity equations, and on a simplified measure of patent status.

Table 17 contains the estimation details for patent status ("stage 0") and the first stage IV regressions, where we define "patented" as having any patent protection. In stage 0, we estimate a linear model for patent status using all explanatory variables (including year, country and drug fixed-effects) plus indicators for whether the priority date fell within the window of TRIPS compliance and for whether the period is within the statutory term of patent protection. The latter are both highly significant and economically meaningful. We then generate predicted values (PatêntedDrug) for patent status, and use these, their square, and their interactions with income groups as instruments for patent status in the price and quantity regressions. Standard tests indicate that these instruments are valid.

Table 18 contains the results of IV estimation of price and quantity, with OLS included for comparison. While the OLS estimates indicate only small differences in price or quantity associated with patents, the IV estimates point to a much larger effect. The price premium associated with 
patent protection is large and significant for all income groups except the poorest. This makes intuitive sense: while patents provide some market power, its exercise (through setting high prices) is likely to be limited where purchasing power is very low. In rich countries, patents allow the use of much higher markups. The IV estimates also suggest more use of differential pricing for patented drugs than do the OLS. Patented drugs sell in higher quantities in most income groups.

The IV estimates rely on the variation explained by the exogenous option of post-TRIPS protection and pre-determined statutory patent terms, and provide the local average treatment effect of patents for the subset of cases where this variation changed patent status. The estimated local average treatment effect of patent status for these products may not be representative for all drugs.

\subsection{Discussion}

Most of the debate about patented drugs is focused on price, with concerns that patients in poor countries are unable to afford them. We expected patents to be associated with increased prices, if patent holders are able to exploit their market power. In general, this is what we find, and concerns about the effect of IPRs on affordability are certainly valid. However, there are two reasons to be somewhat optimistic about the effects of patents in developing countries. The price premium associated with patents is close to zero, on average, in the lower-middle income countries in our sample. This is true whether we rely on OLS or on IV specifications. These results obscure the changes specific to the implementation of the TRIPS Agreement in developing countries, however. In fact, we find that TRIPS has actually been associated with a smaller price difference attributable to patent protection in the poorest countries in our sample. Pre-TRIPS patented drugs are relatively more expensive there. The price premium associated with patents is highest in rich countries, and our estimates of this premium are higher when we control for the endogeneity of patent protection.

Two other measures of access receive less attention, but are worthy of discussion. Most of our specifications find little difference in the quantities sold associated with patent status, although the IV estimates show a more worrisome picture in poor countries. Drugs with post-TRIPS patents have higher sales than those without such protection, however. This suggests that originators invest in efforts to shift out demand when IPRs protect them from generic competition. Since advertising and investments in educating patients or health care practitioners would generally spill over to competitors, it makes sense that originators underinvest in them when facing generic imitation. We did not have a clear prediction for the effect of patents on launch, but we find across all specifications that launch of new products is faster in the presence of patents. As was evident from the summary statistics, patents are not the only barrier to generic entry in practice: even when patents do not exist, generics may not enter, and they rarely enter first in most markets.

Cockburn et al. (2014), in a study of country-level patent policy and launch incentives in an earlier period than that covered here, also emphasize the importance of IPRs and access. They found interesting differences for countries that offered only short process patents versus those with 
long product patents, but TRIPS has eliminated these cross-country differences. Other authors who have conducted a recent analysis of the pharmaceutical market in one important developing country, India, find only a small increase in price post-TRIPS (Duggan et al. (2014)) and note the substantial launch delays associated with weak patent protection (Berndt \& Cockburn (2014)). Our results are broadly consistent with these recent contributions. However, all of these papers use market data from IMS Health, which does not necessarily cover all distribution channels, particularly in developing countries. We believe it is the best available source for a multi-country study of a large cross-section of products. Studies that use alternative sources or that focus on a specific disease area, particularly those in which NGOs are active in distribution and not sampled by IMS, may yield different results. Chaudhuri et al. (2006) is one such example, and identifying cases where patents have had more negative consequences is important for adjusting policy.

In our description of the TRIPS Agreement, we noted several exceptions that developing countries negotiated. These include the right to use price controls and the right to issue compulsory licenses (both of which have also been invoked by rich countries). One explanation for the observed post-TRIPS reduction in price in lower middle income and low income countries is that these countries exercised more stringent price controls on pharmaceuticals at the same time they introduced stronger patents. India established a panel to examine regulating the price of patented medicines in 2007, shortly after its TRIPS compliance deadline in 2005. Originators may still expect higher profits with price controls if they are not sharing the market with generic imitators, so launch would be more attractive. We find some evidence for this. So far, the use of compulsory licensing has been limited. Beall \& Kuhn (2012) identified only 34 potential compulsory licenses in 26 countries by 2011. Of course, originators may have started to reduce prices post-TRIPS or to use voluntary licensing in order to make compulsory licensing less attractive to governments, or perhaps due to increased attention to corporate social responsibility. For example, to encourage innovators to increase the availability of their products in developing countries, accesstomedicines.org produces an annual index of pharmaceutical firms based on their pricing, licensing, R\&D investments, and other dimensions. Merck and GlaxoSmithKline announced a large price cut on their cervical cancer vaccines for developing countries in May 2013. Gilead, the producer of the hepatitis $\mathrm{C}$ treatment SOVALDI, recently issued voluntary licenses for manufacturers selling in low-income markets. Patent challenges, or attempts to invalidate pharmaceutical patents, may also play a role. Such challenges exist in both developed countries (indeed, the Hatch-Waxman Act in the US provides clear incentives for such challenges) and increasingly in developing countries as well. In addition, countries vary in the definition of the inventive step required to patent an innovation. Sampat et al. (2012) describe the case of India, whose Patent Act does not allow patents on variants of existing pharmaceuticals without proof of increased effectiveness. Garrison (2006) provides a detailed description of other exceptions used by developing countries to limit scope of patent protection. 
The countervailing responses just described are most likely to affect important drugs: those that treat serious diseases with a high local burden. That is, price controls and compulsory licenses are more relevant for HIV or hepatitis treatments than for acne, restless leg syndrome, or erectile dysfunction. We include one final set of specifications that includes country fixed-effects, and allows the effect of patent status to vary by disease burden within a country. These results are presented graphically in Figures 7, 8 and 9. For launch, we find that post-TRIPS patents have been most important for diseases with lower disease burdens. When disease burden is high, our results indicate that drugs with post-TRIPS patents have lower prices (and higher quantities) than with pre-TRIPS patents, and the opposite is true for drugs treating diseases with a lower burden. The results are also consistent with the idea (also noted by Berndt \& Cockburn (2014)) that these policies make product launch less attractive, as we observe a smaller bump in launch for post-TRIPS patents when disease burden is greatest. However, these differences are statistically insignificant, and therefore only suggestive.

There are alternative explanations for a change in prices unrelated to non-IP policy shifts or political pressures. First, if originators are more willing to launch new products when they are protected by IPRs, the set of products available in a market will expand. This larger set of products may include those for which patents shifted the expected quantity sold by the innovator more than the price commanded (especially in relatively poor countries, where demand may be more elastic). In other words, the adoption of patents may have encouraged the launch of products with lower prices, for which innovators could not cover the fixed costs of launch without the assurance of $100 \%$ market share. Another explanation is related to the form of competition in developing markets. While generic products in developed countries are usually considered (nearly) perfect substitutes for the original product, emerging markets often see competition between "branded" generics, where real or perceived quality may vary across firms. In these environments, firms may incur some costs to develop and protect their brand names, or use price to signal quality. It is possible that by allocating the entire market to the originator, TRIPS-related IPRs have eliminated the need to differentiate from other producers of the same molecule; lower costs allow lower prices.

Whether the price changes are voluntary responses by firms or result directly from other policy instruments, our estimates reflect the "net" effect of TRIPS rather than the effect of IPRs alone, and there may be substantial heterogeneity in the outcomes across countries. However, the results suggest that these exemptions largely offset the negative impact of stronger IPRs, conditional on product launch. They may come at some cost: while Kyle \& McGahan (2012) find that IPRs in developing countries have not greatly shifted drug development incentives, the use of price controls in relatively rich markets is associated with launch delays (Kyle (2007)). 


\section{Conclusion}

Our results suggest several points about the relationship between IPRs and access. First, the existence of IPRs is neither necessary nor sufficient for the launch of pharmaceutical innovations at the country level. That is, the existence of patents on a molecule in a country does not always block generic imitation, nor does the lack of patents always deter an originator from making a product available. This suggests substantial heterogeneity in the value of IPRs, both across countries and across drugs. IPRs that are not enforced are worth very little. IPRs on molecules with very high imitation costs or low potential for profit in a country are also not particularly important. While patented products generally command higher prices, we find that the price premium for patent products is smaller following TRIPS compliance. This may reflect the greater use of pharmaceutical price controls, bargaining power of government purchasers or the threat of compulsory licensing in order to offset some of the market power granted by IPRs. Post-TRIPS patented drugs enjoy higher sales. Finally, IPRs have a very large bearing on product launch. Thus, while the potential for patents to limit access is often emphasized in policy discussions, it appears that IPRs - by creating increased incentives for marketing efforts by originators - may increase the availability of new treatments to populations in developing countries.

The TRIPS Agreement, which generally strengthened and harmonized IPRs across countries, does appear to have changed market outcomes. On average, access to new pharmaceuticals has at least not decreased following TRIPS. Point estimates show an increase in the probability of new product launch and quantities sold, although differences are not always statistically significant. While patents are also associated with higher prices, there is some evidence that prices in poorer countries have fallen, though not to the level of off-patent products. However, the effect of IPRs may be confounded by other policy changes. It is certainly possible that in the absence of countervailing policies, stronger IPRs would have resulted in a larger increase in prices. It is also likely that IPRs have very different implications for countries with a large generic sector (e.g., India) than for most of the developing countries we examine. Nevertheless, we believe the results should be considered relatively good news about the relationship between IPRs and access to innovative medicines, although considerable work remains to improve the latter.

\section{References}

Arora, A., Branstetter, L., \& Chatterjee, C. (2008). Strong Medicine: Patent Reform and the Emergence of a Research-Driven Pharmaceutical Industry in India.

Bate, R., Jin, G. Z., \& Mathur, A. (2014a). Falsified or substandard? assessing price and non-price signals of drug quality. Journal of Economics and Management Strategy, forthcoming. 
Bate, R., Jin, G. Z., Mathur, A., \& Attaran, A. (2014b). Poor drug quality and global trade: A pilot study. NBER Working Paper 20469.

Beall, R., \& Kuhn, R. (2012). Trends in Compulsory Licensing of Pharmaceuticals Since the Doha Declaration: A Database Analysis. PLoS Medicine, 9(1), e1001154.

Berndt, E. R., Blalock, N., \& Cockburn, I. M. (2011). Diffusion of new drugs in the post-trips era. International Journal of the Economics of Business, 18(2), 203-224.

Berndt, E. R., \& Cockburn, I. M. (2014). The hidden cost of low prices: Limited access to new drugs in india. Health Affairs, 33(9), 1567-1575.

Boldrin, M., \& Levine, D. (2002). The Case Against Intellectual Property. American Economic Review Papers and Proceedings, 92, 209-212.

Borrell, J.-R. (2005). Patents and the faster introduction of new drugs in developing countries. Applied Economics Letters, 12(2), 379-382.

Chaudhuri, S., Goldberg, P., \& Jia, P. (2006). Estimating the Effects of Global Patent Protection in Pharmaceuticals: A Case Study of Quinilones in India. American Economic Review, 96(5), $1477-1513$.

Cockburn, I., Lanjouw, J., \& Schankerman, M. (2014). Global diffusion of new drugs: The role of patent policy, price controls and institutions. NBER Working Paper 20492.

Cohen, W., Nelson, R., \& Walsh, J. (2000). Protecting their Intellectual Assets: Appropriability Conditions and Why U.S. Manufacturing Firms Patent (or Not). NBER Working Paper 7552.

Danzon, P. M., \& Epstein, A. (2008). Effects of Regulation on Drug Launch and Pricing in Interdependent Markets. NBER Working Paper 14041.

Danzon, P. M., Wang, R., \& Wang, L. (2005). The Impact of Price Regulation on the Launch Delay of New Drugs - Evidence from Twenty-five Major Markets in the 1990s. Health Economics, 14, 269-292.

Duggan, M., Garthwaite, C., \& Goyal, A. (2014). The market impacts of pharmaceutical product patents in developing countries: Evidence from India. NBER Working Paper 20548.

Garrison, C. (2006). Exceptions to Patent Rights in Developing Countries. Tech. rep., International Centre for Trade and Sustainable Development.

Ginarte, J., \& Park, W. (1997). Determinants of Patent Rights: A Cross-National Study. Research Policy, 26(3), 283-301. 
Hamdan-Livramento, I. (2009). How compliant are developing countries with their TRIPS obligations? CEMI Working Paper 2009-001.

Kyle, M. (2006). The role of firm characteristics in pharmaceutical product launches. $R A N D$ Journal of Economics, 37(3), 602-618.

Kyle, M. (2007). Pharmaceutical price controls and entry strategies. Review of Economics and Statistics, 89(1), 88-99.

Kyle, M., \& McGahan, A. (2012). Investments in pharmaceuticals before and after TRIPS. Review of Economics and Statistics, 94(4), 1157-1172.

LaCroix, S., \& Liu, M. (2008). Patents and Access to Essential Medicines, chap. 13, (pp. 423-464). Frontiers of Economics and Globalization. Elsevier.

LaCroix, S., \& Liu, M. (2014). The impact of stronger property rights in pharmaceuticals on innovation in developed and developing countries.

Lanjouw, J. (2005). Patents, price controls and access to new drugs: How policy affects global market entry. NBER Working Paper 11321.

Lanjouw, J., \& Cockburn, I. (2001). Do patents matter? Empirical evidence after GATT. NBER Working Paper 7495.

Qian, Y. (2007). Do Additional National Patent Laws Stimulate Domestic Innovation in an International Patenting Environment? Review of Economics and Statistics, 89(3), 436-453.

Sampat, B. N., Shadlen, K. C., \& Amin, T. M. (2012). Challenges to India's Pharmaceutical Patent Laws. Science, 337, 414-415.

Scott Morton, F., \& Kyle, M. (2012). Markets for Pharmaceutical Products. In M. V. Pauly, T. G. Mcguire, \& P. P. Barros (Eds.) Handbook of Health Economics, vol. 2, chap. 12, (pp. 763-823). Elsevier.

Waning, B., Diedrichsen, E., \& Moon, S. (2010). A lifeline to treatment: the role of Indian generic manufacturers in supplying antiretroviral medicines to developing countries. Journal of the International AIDS Society, 13(35).

Wooldridge, J. (2010). Econometric Analysis of Cross-section and Panel Data. MIT Press, 2nd ed. 
Table 1: Distribution of country characteristics

\begin{tabular}{cc}
\hline Year of TRIPS compliance deadline & $\mathrm{N}$ \\
1995 & 25 \\
1996 & 1 \\
1999 & 1 \\
2000 & 16 \\
2001 & 2 \\
2005 & 12 \\
2012 & 1 \\
Total & 58 \\
\hline Income group (2000) & $\mathrm{N}$ \\
High OECD & 20 \\
High nonOECD & 4 \\
Upper middle & 17 \\
Lower middle & 16 \\
Low income & 3 \\
Total & 60 \\
\hline WDI geographic region & $\mathrm{N}$ \\
East Asia \& Pacific & 10 \\
Europe \& Central Asia & 27 \\
Latin America \& Caribbean & 9 \\
Middle East \& North Africa & 9 \\
North America & 2 \\
South Asia & 2 \\
Sub-Saharan Africa & 1 \\
Total & 60 \\
\hline & \\
\hline
\end{tabular}

Table 2: Distribution of molecules across diseases

\begin{tabular}{cc}
\hline Disease & $\mathrm{N}$ \\
\hline Infectious and parasitic & 102 \\
Respiratory & 49 \\
Nutritional deficiencies & 3 \\
Neoplasms & 116 \\
Diabetes & 36 \\
Endocrine & 11 \\
Neuropsychotic & 92 \\
Sense organ & 10 \\
Cardiovascular & 136 \\
Digestive & 44 \\
Genitourinary & 41 \\
Skin & 36 \\
Musculoskeletal & 39 \\
Oral & 1 \\
Total & 716 \\
\hline
\end{tabular}


Table 3: Access and price by income group and patent status

\begin{tabular}{llllll}
\hline & $\begin{array}{l}\text { Launch } \\
(\text { mean })\end{array}$ & $\begin{array}{l}\text { Originator } \\
\text { 1st (mean) }\end{array}$ & $\begin{array}{l}\text { Orig. launch } \\
\text { (median yrs) }\end{array}$ & $\begin{array}{l}\text { Any generic } \\
\text { (mean) }\end{array}$ & $\begin{array}{l}\text { Generic launch } \\
\text { (median yrs) }\end{array}$ \\
\hline High OECD & 0.55 & 0.86 & 1.50 & 0.28 & 7.76 \\
High nonOECD & 0.40 & 0.82 & 2.75 & 0.25 & 4.76 \\
Upper middle & 0.44 & 0.79 & 2.76 & 0.39 & 7.01 \\
Lower middle & 0.35 & 0.69 & 3.75 & 0.49 & 7.26 \\
\hline Never patented & 0.31 & 0.73 & 3.51 & 0.43 & 7.50 \\
Ever patented & 0.59 & 0.84 & 1.75 & 0.32 & 7.01 \\
Ever product patent & 0.60 & 0.84 & 1.50 & 0.31 & 7.01 \\
\hline Total & 0.45 & 0.80 & 2.25 & 0.36 & 7.25 \\
\hline
\end{tabular}

Table 4: Patenting and launch activity over time

\begin{tabular}{ccc}
\hline & \multicolumn{2}{c}{ Mean number } \\
& Patent countries & Launch countries \\
\hline First global launch & & \\
$1990-1994$ & 14.00 & 22.30 \\
$1995-1999$ & 20.33 & 31.08 \\
$2000-2004$ & 31.00 & 29.43 \\
$2005-2009$ & 36.40 & 25.94 \\
Post-2010 & 32.33 & 14.25 \\
\hline Total & 31.06 & 26.01 \\
\hline
\end{tabular}


Figure 1: Number of producers by patent status

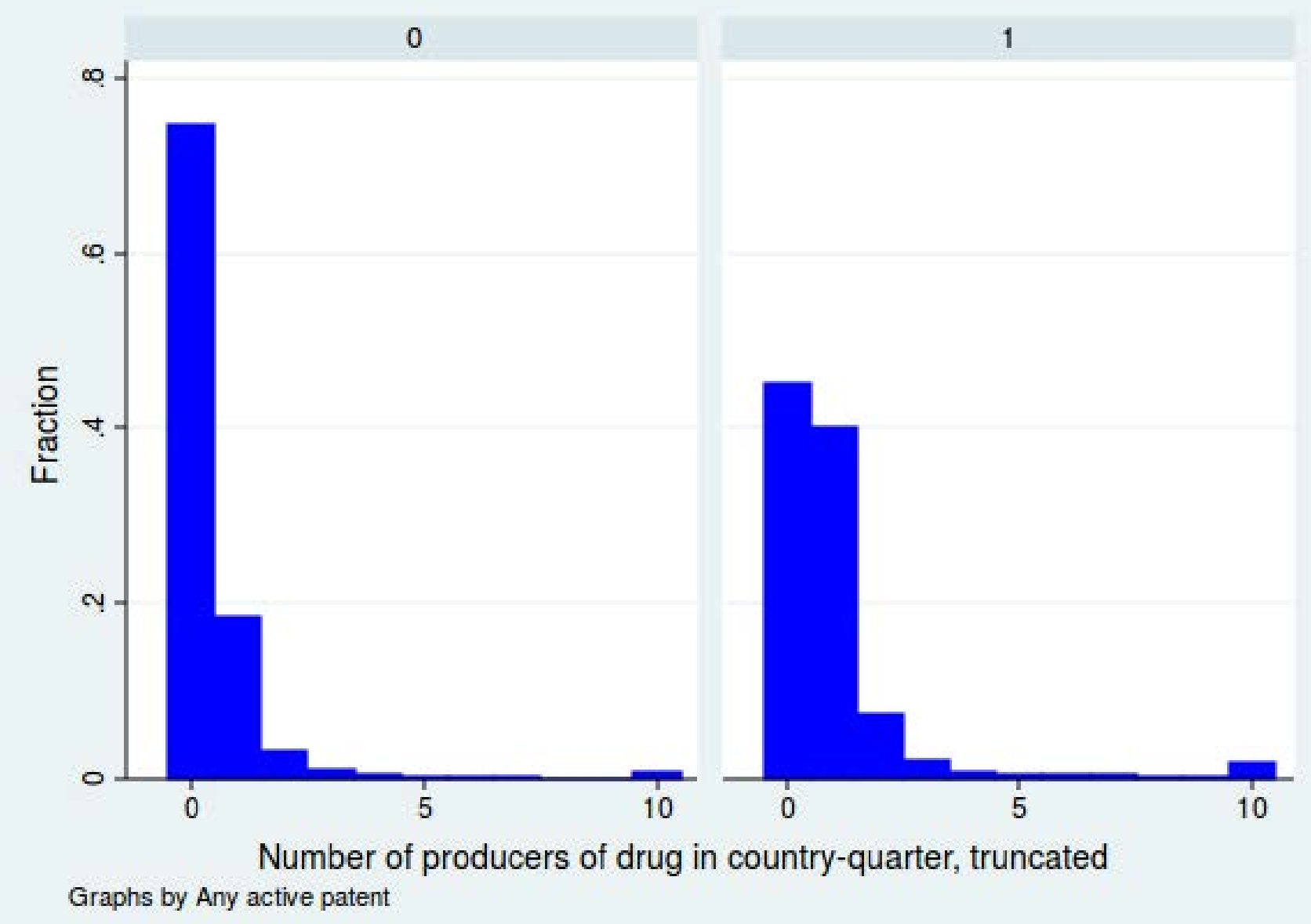




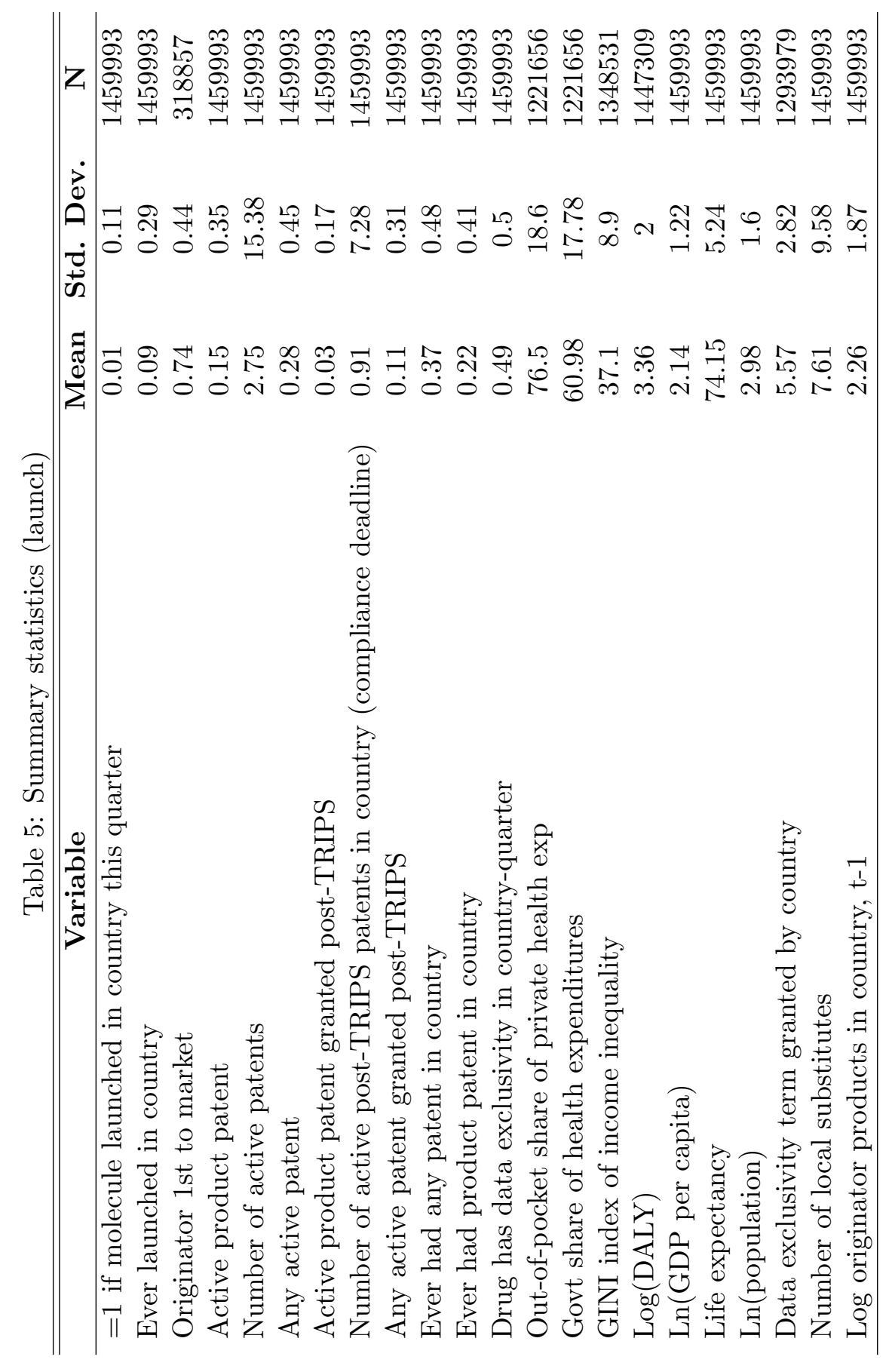




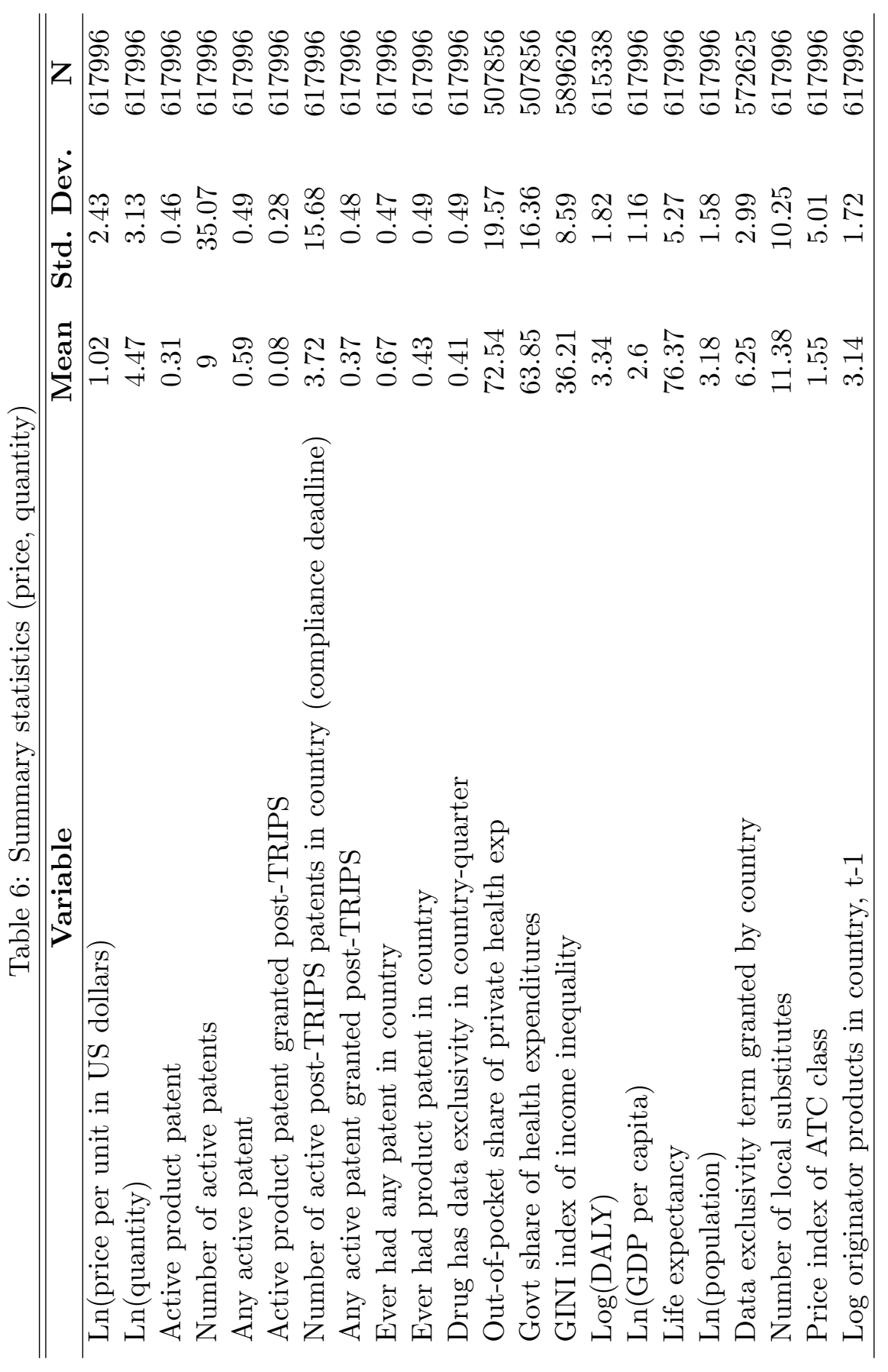


Table 7: Main Effect of Product Patent

\begin{tabular}{|c|c|c|c|}
\hline & $\begin{array}{l}\text { Launch } \\
\mathrm{b} / \mathrm{se}\end{array}$ & $\begin{array}{l}\text { Price } \\
\mathrm{b} / \mathrm{se}\end{array}$ & $\begin{array}{l}\text { Quantity } \\
\text { b/se }\end{array}$ \\
\hline Expired patent & $\begin{array}{l}0.5969^{* * *} \\
(0.0512)\end{array}$ & $\begin{array}{l}0.3005^{* * *} \\
(0.1082)\end{array}$ & $\begin{array}{c}0.2820^{*} \\
(0.1482)\end{array}$ \\
\hline On patent & $\begin{array}{l}0.8808^{* * *} \\
(0.0538)\end{array}$ & $\begin{array}{l}0.4774^{* * *} \\
(0.1404)\end{array}$ & $\begin{array}{l}0.5324^{* * *} \\
(0.1893)\end{array}$ \\
\hline $\log (\mathrm{DALY})$ & $\begin{array}{c}0.0098 \\
(0.0173)\end{array}$ & $\begin{array}{r}-0.0611^{*} \\
(0.0329)\end{array}$ & $\begin{array}{l}0.1856^{* * *} \\
(0.0571)\end{array}$ \\
\hline Ln(GDP per capita) & $\begin{array}{c}-0.0160 \\
(0.0501)\end{array}$ & $\begin{array}{l}0.2842^{* * *} \\
(0.0995)\end{array}$ & $\begin{array}{l}0.7687^{* * *} \\
(0.1334)\end{array}$ \\
\hline Life expectancy & $\begin{array}{c}0.0160 \\
(0.0111)\end{array}$ & $\begin{array}{c}0.0255 \\
(0.0190)\end{array}$ & $\begin{array}{c}0.0377 \\
(0.0226)\end{array}$ \\
\hline Ln(population) & $\begin{array}{c}0.0186 \\
(0.0290)\end{array}$ & $\begin{array}{c}0.0274 \\
(0.0436)\end{array}$ & $\begin{array}{l}0.7909^{* * *} \\
(0.0599)\end{array}$ \\
\hline Number of local substitutes & $\begin{array}{l}0.0076^{* * *} \\
(0.0015)\end{array}$ & $\begin{array}{c}0.0033 \\
(0.0068)\end{array}$ & $\begin{array}{l}0.0144^{* * *} \\
(0.0047)\end{array}$ \\
\hline Price index of ATC class & $\begin{array}{r}0.0040^{*} \\
(0.0022)\end{array}$ & $\begin{array}{r}-0.0078 \\
(0.0150)\end{array}$ & $\begin{array}{c}-0.0020 \\
(0.0051)\end{array}$ \\
\hline Log originator products in country, t-1 & $\begin{array}{l}0.2102^{* * *} \\
(0.0091)\end{array}$ & $\begin{array}{c}0.0521 \\
(0.0374)\end{array}$ & $\begin{array}{l}0.1097^{* * *} \\
(0.0407)\end{array}$ \\
\hline Intercept & $\begin{array}{c}-6.3602^{* * *} \\
(0.8278)\end{array}$ & $\begin{array}{r}-2.3302^{*} \\
(1.3860)\end{array}$ & $\begin{array}{c}-4.0173^{* *} \\
(1.5793)\end{array}$ \\
\hline $\begin{array}{l}\mathrm{N} \\
\text { Pseudo } R^{2}\end{array}$ & $\begin{array}{r}1112013 \\
.0897\end{array}$ & 620330 & 620330 \\
\hline Adj. $R^{2}$ & & .832 & .765 \\
\hline Fixed effects & $\begin{array}{l}\text { Year } \\
\text { ATC }\end{array}$ & $\begin{array}{l}\text { Year } \\
\text { Drug }\end{array}$ & $\begin{array}{l}\text { Year } \\
\text { Drug }\end{array}$ \\
\hline
\end{tabular}

${ }^{*} \mathrm{p}<0.10,{ }^{* *} \mathrm{p}<0.05,{ }^{* * *} \mathrm{p}<.01$. Standard errors are clustered by country. 
Table 8: Main Effect of Any Patent

\begin{tabular}{|c|c|c|c|}
\hline & $\begin{array}{l}\text { Launch } \\
\text { b/se }\end{array}$ & $\begin{array}{l}\text { Price } \\
\mathrm{b} / \mathrm{se}\end{array}$ & $\begin{array}{l}\text { Quantity } \\
\text { b/se }\end{array}$ \\
\hline Expired patent & $\begin{array}{c}0.5207^{* * *} \\
(0.0754)\end{array}$ & $\begin{array}{c}0.2448^{* *} \\
(0.1042)\end{array}$ & $\begin{array}{c}0.1373 \\
(0.1323)\end{array}$ \\
\hline On patent & $\begin{array}{l}0.7934^{* * *} \\
(0.0501)\end{array}$ & $\begin{array}{l}0.4022^{* * *} \\
(0.1251)\end{array}$ & $\begin{array}{c}0.4477^{* *} \\
(0.1730)\end{array}$ \\
\hline $\log (\mathrm{DALY})$ & $\begin{array}{c}0.0123 \\
(0.0172)\end{array}$ & $\begin{array}{r}-0.0618^{*} \\
(0.0328)\end{array}$ & $\begin{array}{l}0.1843^{* * *} \\
(0.0571)\end{array}$ \\
\hline Ln(GDP per capita) & $\begin{array}{c}-0.0098 \\
(0.0496)\end{array}$ & $\begin{array}{l}0.2929^{* * *} \\
(0.0996)\end{array}$ & $\begin{array}{l}0.7758^{* * *} \\
(0.1346)\end{array}$ \\
\hline Life expectancy & $\begin{array}{c}0.0157 \\
(0.0109)\end{array}$ & $\begin{array}{c}0.0252 \\
(0.0192)\end{array}$ & $\begin{array}{c}0.0373 \\
(0.0227)\end{array}$ \\
\hline Ln(population) & $\begin{array}{c}0.0212 \\
(0.0286)\end{array}$ & $\begin{array}{c}0.0310 \\
(0.0431)\end{array}$ & $\begin{array}{l}0.7948^{* * *} \\
(0.0601)\end{array}$ \\
\hline Number of local substitutes & $\begin{array}{l}0.0079^{* * *} \\
(0.0015)\end{array}$ & $\begin{array}{c}0.0034 \\
(0.0069)\end{array}$ & $\begin{array}{l}0.0145^{* * *} \\
(0.0047)\end{array}$ \\
\hline Price index of ATC class & $\begin{array}{c}0.0041^{*} \\
(0.0022)\end{array}$ & $\begin{array}{r}-0.0078 \\
(0.0151)\end{array}$ & $\begin{array}{c}-0.0020 \\
(0.0051)\end{array}$ \\
\hline Log originator products in country, t- 1 & $\begin{array}{l}0.2117^{* * *} \\
(0.0091)\end{array}$ & $\begin{array}{c}0.0529 \\
(0.0373)\end{array}$ & $\begin{array}{l}0.1112^{* * *} \\
(0.0410)\end{array}$ \\
\hline Intercept & $\begin{array}{c}-6.3394^{* * *} \\
(0.8118)\end{array}$ & $\begin{array}{r}-2.3440^{*} \\
(1.4011)\end{array}$ & $\begin{array}{c}-4.0242^{* *} \\
(1.5852)\end{array}$ \\
\hline $\begin{array}{l}\mathrm{N} \\
\text { Pseudo } R^{2} \\
\text { Adj. } R^{2}\end{array}$ & $\begin{array}{r}1112013 \\
.0892\end{array}$ & 620330 & 620330 \\
\hline Fixed effects & $\begin{array}{l}\text { Year } \\
\text { ATC }\end{array}$ & $\begin{array}{l}\text { Year } \\
\text { Drug }\end{array}$ & $\begin{array}{l}\text { Year } \\
\text { Drug }\end{array}$ \\
\hline
\end{tabular}

${ }^{*} \mathrm{p}<0.10,{ }^{* *} \mathrm{p}<0.05,{ }^{* * *} \mathrm{p}<.01$. Standard errors are clustered by country. 
Table 9: Main Effect of Product Patent with Country Fixed Effects

\begin{tabular}{lccc}
\hline & Launch & Price & Quantity \\
& $\mathrm{b} / \mathrm{se}$ & $\mathrm{b} / \mathrm{se}$ & $-0.1022^{* *}$ \\
\hline Expired patent & $0.5688^{* * *}$ & $0.0544^{*}$ & $(0.0453)$ \\
& $(0.0403)$ & $(0.0309)$ & 0.0701 \\
On patent & $0.9335^{* * *}$ & $0.1114^{* * *}$ & $(0.0479)$ \\
& $(0.0430)$ & $(0.0315)$ & $0.2474^{* * *}$ \\
Log(DALY) & $0.0323^{* * *}$ & $-0.0856^{* * *}$ & $(0.0357)$ \\
& $(0.0123)$ & $(0.0184)$ & $1.0887^{* * *}$ \\
Ln(GDP per capita) & -0.3091 & $-0.4720^{* * *}$ & $(0.2364)$ \\
& $(0.2191)$ & $(0.1533)$ & $0.0723^{*}$ \\
Life expectancy & -0.0445 & -0.0209 & $(0.0375)$ \\
& $(0.0369)$ & $(0.0228)$ & $1.0348^{*}$ \\
Ln(population) & $-0.5978^{*}$ & $-0.5537^{* *}$ & $(0.5997)$ \\
& $(0.3065)$ & $(0.2184)$ & $0.0133^{* * *}$ \\
Number of local substitutes & $0.0047^{* * *}$ & $0.0061^{*}$ & $(0.0039)$ \\
Price index of ATC class & $(0.0013)$ & $(0.0032)$ & -0.0041 \\
& $0.0049^{* * *}$ & $0.0175^{* * *}$ & $(0.0030)$ \\
Log originator products in country, t-1 & $(0.0017)$ & $(0.0039)$ & $0.1049^{* * *}$ \\
& $0.2031^{* * *}$ & -0.0060 & $(0.0246)$ \\
Intercept & $(0.0096)$ & $(0.0157)$ & $-7.0032^{*}$ \\
& -0.1872 & 1.6295 & $(3.8635)$ \\
\hline N & $(3.3910)$ & $(2.0516)$ & 620330 \\
Adj. $R^{2}$ & 1112013 & 620330 & .800 \\
\hline Fixed effects & .0972 & & Year \\
& & .886 & Country \\
\hline p $<0.10, * *$ p $<0.05, * * *$ \\
\end{tabular}


Table 10: Main Effect of Any Patent with Country Fixed Effects

\begin{tabular}{lccc}
\hline & Launch & Price & Quantity \\
& $\mathrm{b} / \mathrm{se}$ & $\mathrm{b} / \mathrm{se}$ & $-0.1738^{* * *}$ \\
\hline Expired patent & $0.4699^{* * *}$ & 0.0352 & $(0.0533)$ \\
& $(0.0682)$ & $(0.0354)$ & -0.0019 \\
On patent & $0.8226^{* * *}$ & $0.0854^{* * *}$ & $(0.0413)$ \\
& $(0.0391)$ & $(0.0295)$ & $0.2455^{* * *}$ \\
Log(DALY) & $0.0342^{* * *}$ & $-0.0862^{* * *}$ & $(0.0358)$ \\
& $(0.0124)$ & $(0.0182)$ & $1.0695^{* * *}$ \\
Ln(GDP per capita) & -0.3463 & $-0.4758^{* * *}$ & $(0.2368)$ \\
& $(0.2128)$ & $(0.1556)$ & $0.0740^{*}$ \\
Life expectancy & -0.0416 & -0.0202 & $(0.0372)$ \\
& $(0.0369)$ & $(0.0228)$ & $1.0191^{*}$ \\
Ln(population) & $-0.6389^{* *}$ & $-0.5566^{* *}$ & $(0.6012)$ \\
& $(0.3052)$ & $(0.2191)$ & $0.0135^{* * *}$ \\
Number of local substitutes & $0.0052^{* * *}$ & $0.0062^{*}$ & $(0.0039)$ \\
Price index of ATC class & $(0.0014)$ & $(0.0032)$ & -0.0040 \\
& $0.0050^{* * *}$ & $0.0176^{* * *}$ & $(0.0030)$ \\
Log originator products in country, t-1 & $(0.0017)$ & $(0.0039)$ & $0.1050^{* * *}$ \\
& $0.2051^{* * *}$ & -0.0060 & $(0.0246)$ \\
Intercept & $(0.0096)$ & $(0.0157)$ & $-7.0376^{*}$ \\
& -0.1687 & 1.5943 & $(3.8603)$ \\
\hline N & $(3.4028)$ & $(2.0530)$ & 620330 \\
Adj. $R^{2}$ & 1112013 & 620330 & .800 \\
\hline \multirow{2}{*}{ Fixed effects } & .0965 & & Year \\
& & .886 & Country \\
\hline p $<0.10, * *$ p $<0.05, * * *$ \\
\end{tabular}


Table 11: Estimation Results Using Product Patent by Income

\begin{tabular}{|c|c|c|c|}
\hline & $\begin{array}{l}\text { Launch } \\
\text { b/se }\end{array}$ & $\begin{array}{l}\text { Price } \\
\mathrm{b} / \mathrm{se}\end{array}$ & $\begin{array}{l}\text { Quantity } \\
\text { b/se }\end{array}$ \\
\hline Expired patent & $\begin{array}{l}0.8752^{* * *} \\
(0.1252)\end{array}$ & $\begin{array}{c}0.0813 \\
(0.2035)\end{array}$ & $\begin{array}{r}-0.0642 \\
(0.1114)\end{array}$ \\
\hline On patent & $\begin{array}{l}0.6082^{* * *} \\
(0.1649)\end{array}$ & $\begin{array}{c}0.4293^{*} \\
(0.2336)\end{array}$ & $\begin{array}{r}-0.2438^{*} \\
(0.1417)\end{array}$ \\
\hline $\log ($ GDP per capita $) \times$ expired patent & $\begin{array}{c}-0.1057^{* *} \\
(0.0523)\end{array}$ & $\begin{array}{c}0.0948 \\
(0.0820)\end{array}$ & $\begin{array}{c}0.0033 \\
(0.0458)\end{array}$ \\
\hline $\log ($ GDP per capita $) \times$ on patent & $\begin{array}{c}0.0893 \\
(0.0647)\end{array}$ & $\begin{array}{c}0.0336 \\
(0.0933)\end{array}$ & $\begin{array}{c}0.1233^{* *} \\
(0.0514)\end{array}$ \\
\hline Drug has data exclusivity in country-quarter & & $\begin{array}{c}0.1038 \\
(0.0874)\end{array}$ & $\begin{array}{c}-0.1713^{* * *} \\
(0.0437)\end{array}$ \\
\hline $\log (\mathrm{DALY})$ & $\begin{array}{c}0.0094 \\
(0.0169)\end{array}$ & $\begin{array}{c}-0.0646^{* *} \\
(0.0317)\end{array}$ & $\begin{array}{l}0.2489^{* * *} \\
(0.0357)\end{array}$ \\
\hline Ln(GDP per capita) & $\begin{array}{r}-0.0072 \\
(0.0522)\end{array}$ & $\begin{array}{c}0.2460^{* *} \\
(0.1040)\end{array}$ & $\begin{array}{l}1.0741^{* * *} \\
(0.2329)\end{array}$ \\
\hline Life expectancy & $\begin{array}{c}0.0145 \\
(0.0114)\end{array}$ & $\begin{array}{c}0.0238 \\
(0.0191)\end{array}$ & $\begin{array}{r}0.0724^{*} \\
(0.0375)\end{array}$ \\
\hline Ln(population) & $\begin{array}{c}0.0188 \\
(0.0294)\end{array}$ & $\begin{array}{c}0.0262 \\
(0.0444)\end{array}$ & $\begin{array}{r}1.0173^{*} \\
(0.5983)\end{array}$ \\
\hline Number of local substitutes & $\begin{array}{l}0.0076^{* * *} \\
(0.0015)\end{array}$ & $\begin{array}{c}0.0031 \\
(0.0067)\end{array}$ & $\begin{array}{l}0.0132^{* * *} \\
(0.0039)\end{array}$ \\
\hline Price index of ATC class & $\begin{array}{c}0.0039^{*} \\
(0.0022)\end{array}$ & $\begin{array}{c}-0.0076 \\
(0.0150)\end{array}$ & $\begin{array}{c}-0.0044 \\
(0.0030)\end{array}$ \\
\hline Log originator products in country, t- 1 & $\begin{array}{l}0.2097^{* * *} \\
(0.0093)\end{array}$ & $\begin{array}{c}0.0520 \\
(0.0370)\end{array}$ & $\begin{array}{l}0.1054^{* * *} \\
(0.0248)\end{array}$ \\
\hline Intercept & $\begin{array}{c}-6.2555^{* * *} \\
(0.8823)\end{array}$ & $\begin{array}{c}-2.1219 \\
(1.4121)\end{array}$ & $\begin{array}{r}-6.9197^{*} \\
(3.8464)\end{array}$ \\
\hline $\begin{array}{l}\mathrm{N} \\
\text { Pseudo } R^{2}\end{array}$ & $\begin{array}{r}1112013 \\
.0903\end{array}$ & 620330 & 620330 \\
\hline Adj. $R^{2}$ & & .833 & .801 \\
\hline Fixed effects & $\begin{array}{l}\text { Year } \\
\text { ATC }\end{array}$ & $\begin{array}{l}\text { Year } \\
\text { Drug }\end{array}$ & $\begin{array}{l}\text { Year } \\
\text { Drug }\end{array}$ \\
\hline
\end{tabular}

${ }^{*} \mathrm{p}<0.10,{ }^{* *} \mathrm{p}<0.05,{ }^{* * *} \mathrm{p}<.01$. Standard errors are clustered by country. 
Table 12: Estimation Results Using Any Patent by Income

\begin{tabular}{|c|c|c|c|}
\hline & $\begin{array}{l}\text { Launch } \\
\text { b/se }\end{array}$ & $\begin{array}{l}\text { Price } \\
\mathrm{b} / \mathrm{se}\end{array}$ & $\begin{array}{c}\text { Quantity } \\
\text { b/se }\end{array}$ \\
\hline Expired patent & $\begin{array}{l}1.0157^{* * *} \\
(0.1387)\end{array}$ & $\begin{array}{c}0.0794 \\
(0.2101)\end{array}$ & $\begin{array}{c}-0.0812 \\
(0.1603)\end{array}$ \\
\hline On patent & $\begin{array}{l}0.6256^{* * *} \\
(0.1428)\end{array}$ & $\begin{array}{c}0.2482 \\
(0.2102)\end{array}$ & $\begin{array}{c}-0.1466 \\
(0.1035)\end{array}$ \\
\hline Log $($ GDP per capita $) \times$ expired patent & $\begin{array}{c}-0.2049^{* * *} \\
(0.0592)\end{array}$ & $\begin{array}{c}0.0800 \\
(0.0813)\end{array}$ & $\begin{array}{c}-0.0236 \\
(0.0606)\end{array}$ \\
\hline $\log ($ GDP per capita $) \times$ on patent & $\begin{array}{c}0.0566 \\
(0.0589)\end{array}$ & $\begin{array}{c}0.0717 \\
(0.0879)\end{array}$ & $\begin{array}{c}0.0651 \\
(0.0431)\end{array}$ \\
\hline Drug has data exclusivity in country-quarter & & $\begin{array}{c}0.1081 \\
(0.0868)\end{array}$ & $\begin{array}{c}-0.1639^{* * *} \\
(0.0441)\end{array}$ \\
\hline $\log (\mathrm{DALY})$ & $\begin{array}{c}0.0118 \\
(0.0167)\end{array}$ & $\begin{array}{c}-0.0651^{* *} \\
(0.0316)\end{array}$ & $\begin{array}{l}0.2460^{* * *} \\
(0.0358)\end{array}$ \\
\hline Ln(GDP per capita) & $\begin{array}{c}-0.0033 \\
(0.0518)\end{array}$ & $\begin{array}{c}0.2503^{* *} \\
(0.1038)\end{array}$ & $\begin{array}{l}1.0710^{* * *} \\
(0.2341)\end{array}$ \\
\hline Life expectancy & $\begin{array}{c}0.0142 \\
(0.0111)\end{array}$ & $\begin{array}{c}0.0231 \\
(0.0193)\end{array}$ & $\begin{array}{c}0.0738^{*} \\
(0.0371)\end{array}$ \\
\hline Ln(population) & $\begin{array}{c}0.0216 \\
(0.0287)\end{array}$ & $\begin{array}{c}0.0284 \\
(0.0442)\end{array}$ & $\begin{array}{r}1.0135^{*} \\
(0.5983)\end{array}$ \\
\hline Number of local substitutes & $\begin{array}{l}0.0080^{* * *} \\
(0.0016)\end{array}$ & $\begin{array}{c}0.0030 \\
(0.0068)\end{array}$ & $\begin{array}{l}0.0133^{* * *} \\
(0.0039)\end{array}$ \\
\hline Price index of ATC class & $\begin{array}{c}0.0040^{*} \\
(0.0022)\end{array}$ & $\begin{array}{c}-0.0076 \\
(0.0150)\end{array}$ & $\begin{array}{c}-0.0041 \\
(0.0030)\end{array}$ \\
\hline Log originator products in country, t- 1 & $\begin{array}{l}0.2113^{* * *} \\
(0.0093)\end{array}$ & $\begin{array}{c}0.0526 \\
(0.0371)\end{array}$ & $\begin{array}{l}0.1067^{* * *} \\
(0.0248)\end{array}$ \\
\hline Intercept & $\begin{array}{c}-6.2356^{* * *} \\
(0.8629)\end{array}$ & $\begin{array}{c}-2.0887 \\
(1.4246)\end{array}$ & $\begin{array}{r}-7.0005^{*} \\
(3.8367)\end{array}$ \\
\hline $\begin{array}{l}\mathrm{N} \\
\text { Pseudo } R^{2}\end{array}$ & $\begin{array}{c}1112013 \\
.09\end{array}$ & 620330 & 620330 \\
\hline Adj. $R^{2}$ & & .832 & .8 \\
\hline Fixed effects & $\begin{array}{l}\text { Year } \\
\text { ATC }\end{array}$ & $\begin{array}{l}\text { Year } \\
\text { Drug }\end{array}$ & $\begin{array}{l}\text { Year } \\
\text { Drug }\end{array}$ \\
\hline
\end{tabular}

${ }^{*} \mathrm{p}<0.10,{ }^{* *} \mathrm{p}<0.05,{ }^{* * *} \mathrm{p}<.01$. Standard errors are clustered by country. 
Table 13: Estimation Results Using Product Patent by Income Group

\begin{tabular}{|c|c|c|c|}
\hline & $\begin{array}{c}\text { Launch } \\
\text { b/se }\end{array}$ & $\begin{array}{l}\text { Price } \\
\mathrm{b} / \mathrm{se}\end{array}$ & $\begin{array}{l}\text { Quantity } \\
\text { b/se }\end{array}$ \\
\hline \multirow[t]{2}{*}{ Expired patent } & $0.6929^{* * *}$ & $0.2609^{* * *}$ & $0.3298^{* *}$ \\
\hline & $(0.1661)$ & $(0.0819)$ & $(0.1542)$ \\
\hline \multirow[t]{2}{*}{ On patent } & $1.1871^{* * *}$ & $0.4028^{* * *}$ & $0.6940^{* * *}$ \\
\hline & $(0.1749)$ & $(0.1132)$ & $(0.1997)$ \\
\hline \multirow[t]{2}{*}{ High nonOECD $\times$ expired patent } & 0.0916 & -0.0233 & 0.5445 \\
\hline & $(0.1779)$ & $(0.1528)$ & $(0.3410)$ \\
\hline \multirow[t]{2}{*}{ Upper middle $\times$ expired patent } & 0.0184 & 0.2211 & -0.1752 \\
\hline & $(0.1740)$ & $(0.1882)$ & $(0.1910)$ \\
\hline \multirow[t]{2}{*}{ Lower middle $\times$ expired patent } & 0.0009 & -0.2943 & -0.1464 \\
\hline & $(0.1863)$ & $(0.1886)$ & $(0.2016)$ \\
\hline \multirow{2}{*}{ High nonOECD $\times$ on patent } & -0.2495 & -0.0674 & 0.2960 \\
\hline & $(0.1932)$ & $(0.1751)$ & $(0.4699)$ \\
\hline \multirow[t]{2}{*}{ Upper middle $\times$ on patent } & $-0.4282^{* *}$ & 0.2080 & $-0.6153^{* *}$ \\
\hline & $(0.1810)$ & $(0.2100)$ & $(0.2491)$ \\
\hline \multirow[t]{2}{*}{ Lower middle $\times$ on patent } & $-0.4806^{* *}$ & -0.0994 & $-0.5539^{*}$ \\
\hline & $(0.2078)$ & $(0.1936)$ & $(0.2773)$ \\
\hline \multirow{2}{*}{ Drug has data exclusivity in country-quarter } & & 0.1090 & -0.1145 \\
\hline & & $(0.0863)$ & $(0.0860)$ \\
\hline \multirow[t]{2}{*}{ High nonOECD } & 0.3455 & -0.1788 & $-0.8883^{*}$ \\
\hline & $(0.2217)$ & $(0.1788)$ & $(0.4985)$ \\
\hline \multirow[t]{2}{*}{ Upper middle } & $0.3963^{*}$ & -0.4005 & -0.1766 \\
\hline & $(0.2282)$ & $(0.3831)$ & $(0.3510)$ \\
\hline \multirow[t]{2}{*}{ Lower middle } & 0.2657 & -0.4485 & -0.4956 \\
\hline & $(0.2647)$ & $(0.7233)$ & $(0.6062)$ \\
\hline \multirow{2}{*}{$\log (\mathrm{DALY})$} & 0.0141 & $-0.0728^{* *}$ & $0.1574^{* * *}$ \\
\hline & $(0.0154)$ & $(0.0309)$ & $(0.0523)$ \\
\hline \multirow[t]{2}{*}{ Ln(GDP per capita) } & -0.0006 & 0.1338 & $0.6102^{* * *}$ \\
\hline & $(0.0820)$ & $(0.2599)$ & $(0.2235)$ \\
\hline \multirow{2}{*}{ Life expectancy } & 0.0186 & 0.0233 & 0.0196 \\
\hline & $(0.0120)$ & $(0.0167)$ & $(0.0157)$ \\
\hline \multirow[t]{2}{*}{$\operatorname{Ln}$ (population) } & 0.0336 & 0.0179 & $0.7585^{* * *}$ \\
\hline & $(0.0296)$ & $(0.0498)$ & $(0.0640)$ \\
\hline \multirow[t]{2}{*}{ Number of local substitutes } & $0.0076^{* * *}$ & 0.0022 & $0.0122^{* *}$ \\
\hline & $(0.0015)$ & $(0.0063)$ & $(0.0047)$ \\
\hline \multirow[t]{2}{*}{ Price index of ATC class } & 0.0036 & -0.0067 & -0.0027 \\
\hline & $(0.0024)$ & $(0.0141)$ & $(0.0051)$ \\
\hline \multirow[t]{2}{*}{ Log originator products in country, t-1 } & $0.2082^{* * *}$ & 0.0458 & $0.0928^{* *}$ \\
\hline & $(0.0091)$ & $(0.0373)$ & $(0.0358)$ \\
\hline \multirow[t]{2}{*}{ Intercept } & $-6.9383^{* * *}$ & -1.4191 & -1.6939 \\
\hline & $(1.0585)$ & $(1.4676)$ & $(1.1644)$ \\
\hline $\mathrm{N}$ & 1112013 & 620330 & 620330 \\
\hline Pseudo $R^{2}$ & .091 & & \\
\hline Adj. $R^{2}$ & & .834 & .770 \\
\hline \multirow{2}{*}{ Fixed effects } & Year & Year & Year \\
\hline & ATC & Drug & Drug \\
\hline
\end{tabular}

${ }^{*} \mathrm{p}<0.10,{ }^{* *} \mathrm{p}<0.05,{ }^{* * *} \mathrm{p}<.01$. Standard errors are clustered by country. The omitted income group is High income OECD. 
Table 14: Estimation Results Using Any Patent by Income Group

\begin{tabular}{|c|c|c|c|}
\hline & $\begin{array}{l}\text { Launch } \\
\text { b/se }\end{array}$ & $\begin{array}{l}\text { Price } \\
\mathrm{b} / \mathrm{se}\end{array}$ & $\begin{array}{c}\text { Quantity } \\
\text { b/se }\end{array}$ \\
\hline Expired patent & $\begin{array}{c}0.3321^{*} \\
(0.1766)\end{array}$ & $\begin{array}{c}0.1778^{* *} \\
(0.0775)\end{array}$ & $\begin{array}{c}0.1409 \\
(0.1493)\end{array}$ \\
\hline On patent & $\begin{array}{l}1.0817^{* * *} \\
(0.1727)\end{array}$ & $\begin{array}{l}0.3592^{* * *} \\
(0.0987)\end{array}$ & $\begin{array}{l}0.5812^{\text {*** }} \\
(0.1782)\end{array}$ \\
\hline High nonOECD $\times$ expired patent & $\begin{array}{c}0.4396^{* *} \\
(0.2031)\end{array}$ & $\begin{array}{c}0.1214 \\
(0.1533)\end{array}$ & $\begin{array}{c}0.5497^{* *} \\
(0.2689)\end{array}$ \\
\hline Upper middle $\times$ expired patent & $\begin{array}{l}0.3918^{* *} \\
(0.1941)\end{array}$ & $\begin{array}{c}0.2559 \\
(0.1981)\end{array}$ & $\begin{array}{c}-0.1024 \\
(0.1960)\end{array}$ \\
\hline Lower middle $\times$ expired patent & $\begin{array}{c}0.4329^{* *} \\
(0.1956)\end{array}$ & $\begin{array}{c}-0.1976 \\
(0.1918)\end{array}$ & $\begin{array}{r}-0.0197 \\
(0.2275)\end{array}$ \\
\hline High nonOECD $\times$ on patent & $\begin{array}{c}-0.1993 \\
(0.1828)\end{array}$ & $\begin{array}{c}-0.0841 \\
(0.1650)\end{array}$ & $\begin{array}{c}0.3846 \\
(0.4359)\end{array}$ \\
\hline Upper middle $\times$ on patent & $\begin{array}{c}-0.3560^{* *} \\
(0.1780)\end{array}$ & $\begin{array}{c}0.2023 \\
(0.1984)\end{array}$ & $\begin{array}{c}-0.4544^{* *} \\
(0.2206)\end{array}$ \\
\hline Lower middle $\times$ on patent & $\begin{array}{c}-0.4243^{* *} \\
(0.2014)\end{array}$ & $\begin{array}{c}-0.2328 \\
(0.1872)\end{array}$ & $\begin{array}{r}-0.4156^{*} \\
(0.2318)\end{array}$ \\
\hline Drug has data exclusivity in country-quarter & & $\begin{array}{c}0.1124 \\
(0.0858)\end{array}$ & $\begin{array}{r}-0.1040 \\
(0.0865)\end{array}$ \\
\hline High nonOECD & $\begin{array}{c}0.3551 \\
(0.2203)\end{array}$ & $\begin{array}{c}-0.1775 \\
(0.1791)\end{array}$ & $\begin{array}{r}-0.8847^{*} \\
(0.5003)\end{array}$ \\
\hline Upper middle & $\begin{array}{c}0.4205^{*} \\
(0.2263)\end{array}$ & $\begin{array}{r}-0.3907 \\
(0.3859)\end{array}$ & $\begin{array}{c}-0.1651 \\
(0.3459)\end{array}$ \\
\hline Lower middle & $\begin{array}{c}0.3046 \\
(0.2599)\end{array}$ & $\begin{array}{c}-0.4329 \\
(0.7283)\end{array}$ & $\begin{array}{c}-0.4798 \\
(0.5993)\end{array}$ \\
\hline $\log (\mathrm{DALY})$ & $\begin{array}{c}0.0168 \\
(0.0152)\end{array}$ & $\begin{array}{c}-0.0735^{* *} \\
(0.0308)\end{array}$ & $\begin{array}{l}0.1532^{* * *} \\
(0.0524)\end{array}$ \\
\hline Ln(GDP per capita) & $\begin{array}{c}0.0172 \\
(0.0795)\end{array}$ & $\begin{array}{c}0.1413 \\
(0.2610)\end{array}$ & $\begin{array}{l}0.6203^{\text {*** }} \\
(0.2228)\end{array}$ \\
\hline Life expectancy & $\begin{array}{c}0.0185 \\
(0.0118)\end{array}$ & $\begin{array}{c}0.0231 \\
(0.0168)\end{array}$ & $\begin{array}{c}0.0194 \\
(0.0157)\end{array}$ \\
\hline Ln(population) & $\begin{array}{c}0.0387 \\
(0.0289)\end{array}$ & $\begin{array}{c}0.0192 \\
(0.0501)\end{array}$ & $\begin{array}{l}0.7638^{* * *} \\
(0.0640)\end{array}$ \\
\hline Number of local substitutes & $\begin{array}{l}0.0080^{* * *} \\
(0.0015)\end{array}$ & $\begin{array}{c}0.0023 \\
(0.0063)\end{array}$ & $\begin{array}{c}0.0124^{* *} \\
(0.0047)\end{array}$ \\
\hline Price index of ATC class & $\begin{array}{c}0.0038 \\
(0.0023)\end{array}$ & $\begin{array}{c}-0.0068 \\
(0.0141)\end{array}$ & $\begin{array}{c}-0.0025 \\
(0.0051)\end{array}$ \\
\hline Log originator products in country, t-1 & $\begin{array}{l}0.2100^{* * *} \\
(0.0091)\end{array}$ & $\begin{array}{c}0.0473 \\
(0.0375)\end{array}$ & $\begin{array}{c}0.0957^{* * *} \\
(0.0358)\end{array}$ \\
\hline Intercept & $\begin{array}{c}-6.9952^{* * *} \\
(1.0384)\end{array}$ & $\begin{array}{c}-1.4356 \\
(1.4757)\end{array}$ & $\begin{array}{c}-1.7308 \\
(1.1619)\end{array}$ \\
\hline $\begin{array}{l}\mathrm{N} \\
\text { Pseudo } R^{2} \\
\text { Adj. } R^{2}\end{array}$ & $\begin{array}{r}1112013 \\
.0908\end{array}$ & 620330 & 620330 \\
\hline Fixed effects & $\begin{array}{l}\text { Year } \\
\text { ATC }\end{array}$ & $\begin{array}{l}\text { Year } \\
\text { Drug }\end{array}$ & $\begin{array}{l}\text { Year } \\
\text { Drug }\end{array}$ \\
\hline
\end{tabular}

${ }^{*} \mathrm{p}<0.10,{ }^{* *} \mathrm{p}<0.05,{ }^{* * *} \mathrm{p}<.01$. Standard errors are clustered by country. The omitted income group is High income OECD. 
Table 15: Estimation Results Using Product Patent by Income Group and TRIPS Status

\begin{tabular}{|c|c|c|c|}
\hline & $\begin{array}{c}\text { Launch } \\
\text { b/se }\end{array}$ & $\begin{array}{l}\text { Price } \\
\mathrm{b} / \mathrm{se}\end{array}$ & $\begin{array}{c}\text { Quantity } \\
\text { b/se }\end{array}$ \\
\hline \multirow[t]{2}{*}{ Expired patent } & $0.6968^{* * *}$ & $0.2617^{* * *}$ & $0.3229^{* *}$ \\
\hline & $(0.1667)$ & $(0.0821)$ & $(0.1533)$ \\
\hline \multirow[t]{2}{*}{ Pre-TRIPS patent } & $0.8960^{* * *}$ & $0.4085^{* * *}$ & $0.6246^{* * *}$ \\
\hline & $(0.1800)$ & $(0.1171)$ & $(0.2050)$ \\
\hline \multirow[t]{2}{*}{ Post-TRIPS patent } & $1.4513^{* * *}$ & $0.3911^{* * *}$ & $0.8150^{* * *}$ \\
\hline & $(0.1773)$ & $(0.1121)$ & $(0.1929)$ \\
\hline \multirow[t]{2}{*}{ High nonOECD $\times$ Expired patent } & 0.0994 & -0.0245 & 0.5505 \\
\hline & $(0.1786)$ & $(0.1534)$ & $(0.3392)$ \\
\hline \multirow[t]{2}{*}{ Upper middle $\times$ Expired patent } & 0.0128 & 0.2221 & -0.1733 \\
\hline & $(0.1747)$ & $(0.1884)$ & $(0.1900)$ \\
\hline \multirow[t]{2}{*}{ Lower middle $\times$ Expired patent } & -0.0048 & -0.2941 & -0.1416 \\
\hline & $(0.1883)$ & $(0.1888)$ & $(0.2041)$ \\
\hline \multirow[t]{2}{*}{ High nonOECD $\times$ Pre-TRIPS patent } & -0.2771 & -0.0842 & 0.0167 \\
\hline & $(0.1955)$ & $(0.1697)$ & $(0.4598)$ \\
\hline \multirow[t]{2}{*}{ Upper middle $\times$ Pre-TRIPS patent } & -0.2066 & 0.1861 & $-0.6523^{* *}$ \\
\hline & $(0.1876)$ & $(0.2216)$ & $(0.2597)$ \\
\hline \multirow[t]{2}{*}{ Lower middle $\times$ Pre-TRIPS patent } & -0.2351 & 0.0313 & $-0.7167^{* *}$ \\
\hline & $(0.2184)$ & $(0.2549)$ & $(0.3061)$ \\
\hline \multirow[t]{2}{*}{ High nonOECD $\times$ Post-TRIPS patent } & -0.2514 & -0.0594 & 0.5689 \\
\hline & $(0.1835)$ & $(0.1863)$ & $(0.4390)$ \\
\hline \multirow[t]{2}{*}{ Upper middle $\times$ Post-TRIPS patent } & $-0.5416^{* * *}$ & 0.2445 & $-0.4510^{*}$ \\
\hline & $(0.1840)$ & $(0.2048)$ & $(0.2450)$ \\
\hline \multirow[t]{2}{*}{ Lower middle $\times$ Post-TRIPS patent } & $-0.6247^{* * *}$ & -0.3602 & -0.0980 \\
\hline & $(0.2116)$ & $(0.2977)$ & $(0.2542)$ \\
\hline \multirow[t]{2}{*}{ Drug has data exclusivity in country-quarter } & & 0.1113 & -0.1224 \\
\hline & & $(0.0857)$ & $(0.0846)$ \\
\hline \multirow[t]{2}{*}{ High nonOECD } & $0.3741^{*}$ & -0.1795 & $-0.8713^{*}$ \\
\hline & $(0.2218)$ & $(0.1797)$ & $(0.4967)$ \\
\hline \multirow[t]{2}{*}{ Upper middle } & $0.4490^{* *}$ & -0.4007 & -0.1598 \\
\hline & $(0.2273)$ & $(0.3807)$ & $(0.3423)$ \\
\hline \multirow[t]{2}{*}{ Lower middle } & 0.3438 & -0.4482 & -0.4735 \\
\hline & $(0.2616)$ & $(0.7189)$ & $(0.5886)$ \\
\hline \multirow[t]{2}{*}{$\log (\mathrm{DALY})$} & 0.0180 & $-0.0734^{* *}$ & $0.1615^{* * *}$ \\
\hline & $(0.0155)$ & $(0.0309)$ & $(0.0521)$ \\
\hline \multirow{2}{*}{ Ln(GDP per capita) } & 0.0277 & 0.1329 & $0.6156^{* * *}$ \\
\hline & $(0.0810)$ & $(0.2582)$ & $(0.2158)$ \\
\hline \multirow[t]{2}{*}{ Life expectancy } & 0.0193 & 0.0237 & 0.0207 \\
\hline & $(0.0123)$ & $(0.0170)$ & $(0.0152)$ \\
\hline \multirow[t]{2}{*}{ Ln(population) } & 0.0428 & 0.0178 & $0.7625^{* * *}$ \\
\hline & $(0.0293)$ & $(0.0499)$ & $(0.0631)$ \\
\hline Number of local substitutes & $0.0070^{* * *}$ & 0.0022 & $0.0120^{* *}$ \\
\hline & $(0.0014)$ & $(0.0063)$ & $(0.0047)$ \\
\hline Price index of ATC class & $0.0037^{*}$ & -0.0068 & -0.0025 \\
\hline & $(0.0022)$ & $(0.0142)$ & $(0.0052)$ \\
\hline Log originator products in country, t-1 & $0.2041^{* * *}$ & 0.0443 & $0.0945^{* *}$ \\
\hline & $(0.0091)$ & $(0.0370)$ & $(0.0358)$ \\
\hline Intercept & $-7.2389^{* * *}$ & -1.4371 & -1.8535 \\
\hline & $(1.0773)$ & $(1.4851)$ & $(1.1392)$ \\
\hline $\mathrm{N}$ & 1112013 & 620330 & 620330 \\
\hline Pseudo $R^{2}$ & .0926 & & \\
\hline Adj. $R^{2}$ & & .834 & .771 \\
\hline & Year & Year & Year \\
\hline Fixed effects & ATC & Drug & Drug \\
\hline
\end{tabular}

${ }^{*} \mathrm{p}<0.10,{ }^{* *} \mathrm{p}<0.05,{ }^{* * *} \mathrm{p}<.01$. Standard errors are clustered by country. The omitted income group is High income OECD. 
Table 16: Estimation Results Using Any Patent by Income Group and TRIPS Status

\begin{tabular}{|c|c|c|c|}
\hline & $\begin{array}{c}\text { Launch } \\
\text { b/se }\end{array}$ & $\begin{array}{l}\text { Price } \\
\mathrm{b} / \mathrm{se}\end{array}$ & $\begin{array}{c}\text { Quantity } \\
\text { b/se }\end{array}$ \\
\hline \multirow[t]{2}{*}{ Expired patent } & $0.3314^{*}$ & $0.1762^{* *}$ & 0.1347 \\
\hline & $(0.1764)$ & $(0.0770)$ & $(0.1473)$ \\
\hline \multirow[t]{2}{*}{ Pre-TRIPS patent } & $0.6415^{* * *}$ & $0.3108^{* * *}$ & $0.3799^{* *}$ \\
\hline & $(0.1671)$ & $(0.0936)$ & $(0.1698)$ \\
\hline \multirow[t]{2}{*}{ Post-TRIPS patent } & $1.3160^{* * *}$ & $0.3937^{* * *}$ & $0.7250^{* * *}$ \\
\hline & $(0.1754)$ & $(0.1069)$ & $(0.1814)$ \\
\hline \multirow{2}{*}{ High nonOECD $\times$ Expired patent } & $0.4358^{* *}$ & 0.1183 & $0.5563^{* *}$ \\
\hline & $(0.2036)$ & $(0.1540)$ & $(0.2690)$ \\
\hline \multirow[t]{2}{*}{ Upper middle $\times$ Expired patent } & $0.3817^{* *}$ & 0.2623 & -0.0928 \\
\hline & $(0.1940)$ & $(0.1989)$ & $(0.1940)$ \\
\hline \multirow[t]{2}{*}{ Lower middle $\times$ Expired patent } & $0.4205^{* *}$ & -0.1928 & -0.0126 \\
\hline & $(0.1965)$ & $(0.1909)$ & $(0.2288)$ \\
\hline \multirow[t]{2}{*}{ High nonOECD $\times$ Pre-TRIPS patent } & -0.0742 & -0.1146 & 0.1877 \\
\hline & $(0.1941)$ & $(0.1512)$ & $(0.4434)$ \\
\hline \multirow[t]{2}{*}{ Upper middle $\times$ Pre-TRIPS patent } & -0.0017 & 0.2025 & $-0.3779^{*}$ \\
\hline & $(0.1761)$ & $(0.2021)$ & $(0.2158)$ \\
\hline \multirow[t]{2}{*}{ Lower middle $\times$ Pre-TRIPS patent } & -0.0443 & 0.0714 & $-0.5294^{* *}$ \\
\hline & $(0.2011)$ & $(0.2491)$ & $(0.2495)$ \\
\hline \multirow[t]{2}{*}{ High nonOECD $\times$ Post-TRIPS patent } & -0.2495 & -0.0806 & 0.4887 \\
\hline & $(0.1863)$ & $(0.1685)$ & $(0.3937)$ \\
\hline \multirow[t]{2}{*}{ Upper middle $\times$ Post-TRIPS patent } & $-0.4519^{* *}$ & 0.2460 & $-0.3904^{*}$ \\
\hline & $(0.1793)$ & $(0.2066)$ & $(0.2276)$ \\
\hline \multirow[t]{2}{*}{ Lower middle $\times$ Post-TRIPS patent } & $-0.5381^{* *}$ & $-0.5353^{*}$ & -0.1162 \\
\hline & $(0.2113)$ & $(0.2898)$ & $(0.2423)$ \\
\hline \multirow[t]{2}{*}{ Drug has data exclusivity in country-quarter } & & 0.1132 & -0.1232 \\
\hline & & $(0.0846)$ & $(0.0830)$ \\
\hline \multirow[t]{2}{*}{ High nonOECD } & $0.3912^{*}$ & -0.1652 & $-0.8360^{*}$ \\
\hline & $(0.2213)$ & $(0.1806)$ & $(0.4924)$ \\
\hline \multirow[t]{2}{*}{ Upper middle } & $0.4770^{* *}$ & -0.3808 & -0.1145 \\
\hline & $(0.2252)$ & $(0.3771)$ & $(0.3262)$ \\
\hline \multirow[t]{2}{*}{ Lower middle } & 0.3859 & -0.4181 & -0.4099 \\
\hline & $(0.2570)$ & $(0.7151)$ & $(0.5607)$ \\
\hline \multirow[t]{2}{*}{$\log (\mathrm{DALY})$} & 0.0208 & $-0.0730^{* *}$ & $0.1565^{* * *}$ \\
\hline & $(0.0149)$ & $(0.0310)$ & $(0.0522)$ \\
\hline \multirow{2}{*}{ Ln(GDP per capita) } & 0.0431 & 0.1373 & $0.6300^{* * *}$ \\
\hline & $(0.0791)$ & $(0.2556)$ & $(0.2059)$ \\
\hline \multirow[t]{2}{*}{ Life expectancy } & 0.0199 & 0.0251 & 0.0216 \\
\hline & $(0.0125)$ & $(0.0174)$ & $(0.0148)$ \\
\hline \multirow[t]{2}{*}{ Ln(population) } & $0.0485^{*}$ & 0.0190 & $0.7689^{* * *}$ \\
\hline & $(0.0286)$ & $(0.0502)$ & $(0.0622)$ \\
\hline Number of local substitutes & $0.0077^{* * *}$ & 0.0024 & $0.0117^{* *}$ \\
\hline & $(0.0015)$ & $(0.0061)$ & $(0.0046)$ \\
\hline Price index of ATC class & $0.0040^{*}$ & -0.0068 & -0.0019 \\
\hline & $(0.0021)$ & $(0.0140)$ & $(0.0050)$ \\
\hline Log originator products in country, t-1 & $0.2067^{* * *}$ & 0.0437 & $0.0979^{* * *}$ \\
\hline & $(0.0091)$ & $(0.0367)$ & $(0.0354)$ \\
\hline Intercept & $-7.3720^{* * *}$ & -1.5901 & $-2.0368^{*}$ \\
\hline & $(1.0783)$ & $(1.4929)$ & $(1.1084)$ \\
\hline $\mathrm{N}$ & 1112013 & 620330 & 620330 \\
\hline Pseudo $R^{2}$ & .0935 & & \\
\hline Adj. $R^{2}$ & & .835 & .771 \\
\hline & Year & Year & Year \\
\hline Fixed effects & ATC & Drug & Drug \\
\hline
\end{tabular}

$* \mathrm{p}<0.10, * * \mathrm{p}<0.05, * * * \mathrm{p}<.01$. Standard errors are clustered by country. The omitted income group is High income OECD. 
Table 17: 1st Stage IV Estimation Results

\begin{tabular}{|c|c|c|c|c|c|}
\hline & \multirow[b]{2}{*}{$\begin{array}{c}\text { Stage 0 } \\
\text { Patented } \\
\text { b/se }\end{array}$} & \multicolumn{4}{|c|}{ IV first stage regressions } \\
\hline & & $\begin{array}{c}\text { Patented } \\
\text { b/se }\end{array}$ & $\begin{array}{c}\text { Patented* } \\
\text { nonOECD } \\
\text { b/se }\end{array}$ & $\begin{array}{l}\text { Patented* } \\
\text { Upper middle } \\
\text { b/se }\end{array}$ & $\begin{array}{c}\text { Patented* } \\
\text { Lower middle } \\
\text { b/se }\end{array}$ \\
\hline Within window & $\begin{array}{l}0.1817^{* * *} \\
(0.0009)\end{array}$ & & & & \\
\hline Within term & $\begin{array}{l}0.0098^{* * *} \\
(0.0010)\end{array}$ & & & & \\
\hline $\begin{array}{l}\text { Drug has data exclusivity } \\
\text { in country-quarter }\end{array}$ & $\begin{array}{l}-0.0220^{* * *} \\
(0.0007)\end{array}$ & $\begin{array}{l}0.0050^{* * *} \\
(0.0012)\end{array}$ & $\begin{array}{l}0.0007^{* * *} \\
(0.0003)\end{array}$ & $\begin{array}{l}-0.0065^{* * *} \\
(0.0008)\end{array}$ & $\begin{array}{l}-0.0172^{* * *} \\
(0.0006)\end{array}$ \\
\hline $\log (\mathrm{DALY})$ & $\begin{array}{l}-0.0018^{* * *} \\
(0.0004)\end{array}$ & $\begin{array}{l}0.0029^{* * *} \\
(0.0007)\end{array}$ & $\begin{array}{l}-0.0011^{* * *} \\
(0.0002)\end{array}$ & $\begin{array}{l}0.0032^{* * *} \\
(0.0004)\end{array}$ & $\begin{array}{l}0.0017^{* * *} \\
(0.0004)\end{array}$ \\
\hline Ln(GDP per capita) & $\begin{array}{l}0.3396^{* * *} \\
(0.0031)\end{array}$ & $\begin{array}{l}0.2438^{* * *} \\
(0.0062)\end{array}$ & $\begin{array}{l}-0.0184^{* * *} \\
(0.0018)\end{array}$ & $\begin{array}{l}0.1505^{* * *} \\
(0.0040)\end{array}$ & $\begin{array}{l}0.2127^{* * *} \\
(0.0034)\end{array}$ \\
\hline Life expectancy & $\begin{array}{l}0.0274^{* * *} \\
(0.0005)\end{array}$ & $\begin{array}{l}0.0170^{* * *} \\
(0.0010)\end{array}$ & $\begin{array}{l}0.0059^{* * *} \\
(0.0003)\end{array}$ & $\begin{array}{l}0.0019^{* * *} \\
(0.0006)\end{array}$ & $\begin{array}{l}0.0200^{* * *} \\
(0.0005)\end{array}$ \\
\hline Ln(population) & $\begin{array}{l}0.2515^{* * *} \\
(0.0047)\end{array}$ & $\begin{array}{l}0.2563^{* * *} \\
(0.0093)\end{array}$ & $\begin{array}{l}0.1477^{* * *} \\
(0.0027)\end{array}$ & $\begin{array}{l}0.0368^{* * *} \\
(0.0061)\end{array}$ & $\begin{array}{l}0.1425^{* * *} \\
(0.0051)\end{array}$ \\
\hline Number of local substitutes & $\begin{array}{l}0.0012^{* * *} \\
(0.00003)\end{array}$ & $\begin{array}{l}0.0005^{* * *} \\
(0.0001)\end{array}$ & $\begin{array}{l}0.0002^{* * *} \\
(0.00002)\end{array}$ & $\begin{array}{l}0.0005^{* * *} \\
(0.00004)\end{array}$ & $\begin{array}{l}-0.0006^{* * *} \\
(0.0001)\end{array}$ \\
\hline Price index of ATC class & $\begin{array}{l}-0.0001^{*} \\
(0.0001)\end{array}$ & $\begin{array}{l}-0.0004^{* *} \\
(0.0002)\end{array}$ & $\begin{array}{l}0.00004 \\
(0.00005)\end{array}$ & $\begin{array}{l}0.0001 \\
(0.0001)\end{array}$ & $\begin{array}{l}-0.0006^{* * *} \\
(0.0001)\end{array}$ \\
\hline $\begin{array}{l}\text { Log originator products } \\
\text { in country, t- } 1\end{array}$ & $\begin{array}{l}0.0160^{* * *} \\
(0.0004)\end{array}$ & $\begin{array}{l}0.0059^{* * *} \\
(0.0007)\end{array}$ & $\begin{array}{l}0.0027^{* * *} \\
(0.0002)\end{array}$ & $\begin{array}{l}0.0045^{* * *} \\
(0.0005)\end{array}$ & $\begin{array}{l}0.0156^{* * *} \\
(0.0004)\end{array}$ \\
\hline PatêntedDrug & & $\begin{array}{l}0.0982^{* * *} \\
(0.0261)\end{array}$ & $\begin{array}{l}-0.2430^{* * *} \\
(0.0076)\end{array}$ & $\begin{array}{l}-0.9019^{* * *} \\
(0.0170)\end{array}$ & $\begin{array}{l}-1.2048^{* * *} \\
(0.0143)\end{array}$ \\
\hline PatêntedDrug ${ }^{2}$ & & $\begin{array}{l}0.2902^{* * *} \\
(0.0164)\end{array}$ & $\begin{array}{l}0.1111^{* * *} \\
(0.0048)\end{array}$ & $\begin{array}{l}0.3004^{* * *} \\
(0.0108)\end{array}$ & $\begin{array}{l}0.4392^{* * *} \\
(0.0090)\end{array}$ \\
\hline Pate $\widehat{n t e d D}$ rug*High non-OECD & & $\begin{array}{l}0.4312^{* * *} \\
(0.0261)\end{array}$ & $\begin{array}{l}1.4396^{* * *} \\
(0.0076)\end{array}$ & $\begin{array}{l}0.4694^{* * *} \\
(0.0171)\end{array}$ & $\begin{array}{l}0.5785^{* * *} \\
(0.0143)\end{array}$ \\
\hline Pate $\widehat{n t e d D}$ rug*Upper middle & & $\begin{array}{l}0.0322^{*} \\
(0.0173)\end{array}$ & $\begin{array}{l}0.1091^{* * *} \\
(0.0050)\end{array}$ & $\begin{array}{l}1.4629^{* * *} \\
(0.0113)\end{array}$ & $\begin{array}{l}0.4849^{* * *} \\
(0.0095)\end{array}$ \\
\hline Pate $\widehat{n t e d D}$ rug*Lower middle & & $\begin{array}{l}0.1489^{* * *} \\
(0.0212)\end{array}$ & $\begin{array}{l}0.1613^{* * *} \\
(0.0062)\end{array}$ & $\begin{array}{l}0.5597^{* * *} \\
(0.0139)\end{array}$ & $\begin{array}{l}1.5710^{* * *} \\
(0.0116)\end{array}$ \\
\hline Intercept & $\begin{array}{l}-3.3003^{* * *} \\
(0.0470)\end{array}$ & $\begin{array}{l}-2.1989^{* * *} \\
(0.0872)\end{array}$ & $\begin{array}{l}-0.9238^{* * *} \\
(0.0254)\end{array}$ & $\begin{array}{l}-0.3971^{* * *} \\
(0.0570)\end{array}$ & $\begin{array}{l}-2.0793^{* * *} \\
(0.0479)\end{array}$ \\
\hline $\mathrm{N}$ & 1761836 & 620330 & 620330 & 620330 & 620330 \\
\hline F-statistic & 18544.63 & 1124.43 & 1091.3 & 1075.84 & 728.68 \\
\hline Adj. Partial $R^{2}$ for IVs & & 0.0098 & 0.0759 & 0.0779 & 0.0759 \\
\hline Adj. $R^{2}$ & 0.5660 & 0.5925 & 0.5853 & 0.5818 & 0.4851 \\
\hline Fixed effects & & & $\begin{array}{r}\text { Year } \\
\text { Drug } \\
\text { Count }\end{array}$ & & \\
\hline
\end{tabular}


Table 18: Estimation Results Using Any Patent by Income Group

\begin{tabular}{|c|c|c|c|c|}
\hline & $\begin{array}{l}\text { OLS Price } \\
\mathrm{b} / \mathrm{se}\end{array}$ & $\begin{array}{l}\text { IV Price } \\
\text { b/se }\end{array}$ & $\begin{array}{c}\text { OLS Quantity } \\
\text { b/se }\end{array}$ & $\begin{array}{l}\text { IV Quantity } \\
\text { b/se }\end{array}$ \\
\hline On patent & $\begin{array}{l}0.1002^{* * *} \\
(0.0281)\end{array}$ & $\begin{array}{l}0.2289^{* * *} \\
(0.0527)\end{array}$ & $\begin{array}{l}0.3109^{* * *} \\
(0.0587)\end{array}$ & $\begin{array}{l}1.4202^{* * *} \\
(0.0904)\end{array}$ \\
\hline High nonOECD $\times$ on patent & $\begin{array}{c}0.0146 \\
(0.0562)\end{array}$ & $\begin{array}{l}0.2233^{* * *} \\
(0.0439)\end{array}$ & $\begin{array}{r}-0.2927^{*} \\
(0.1746)\end{array}$ & $\begin{array}{l}-1.4407^{* * *} \\
(0.0752)\end{array}$ \\
\hline Upper middle $\times$ on patent & $\begin{array}{c}-0.0109 \\
(0.0390)\end{array}$ & $\begin{array}{l}0.3394^{* * *} \\
(0.0253)\end{array}$ & $\begin{array}{c}-0.3370^{* * *} \\
(0.0851)\end{array}$ & $\begin{array}{c}-1.2648^{* * *} \\
(0.0433)\end{array}$ \\
\hline Lower middle $\times$ on patent & $\begin{array}{c}-0.1055^{* *} \\
(0.0399)\end{array}$ & $\begin{array}{c}-0.1074^{* * *} \\
(0.0282)\end{array}$ & $\begin{array}{c}-0.3486^{* * *} \\
(0.0852)\end{array}$ & $\begin{array}{c}-0.9603^{* * *} \\
(0.0484)\end{array}$ \\
\hline Drug has data exclusivity in country-quarter & $\begin{array}{c}-0.0063 \\
(0.0216)\end{array}$ & $\begin{array}{c}-0.0039 \\
(0.0031)\end{array}$ & $\begin{array}{c}-0.1639^{* * *} \\
(0.0441)\end{array}$ & $\begin{array}{c}-0.1739^{* * *} \\
(0.0053)\end{array}$ \\
\hline $\log (\mathrm{DALY})$ & $\begin{array}{c}-0.0862^{* * *} \\
(0.0183)\end{array}$ & $\begin{array}{c}-0.0875^{* * *} \\
(0.0018)\end{array}$ & $\begin{array}{l}0.2464^{* * *} \\
(0.0358)\end{array}$ & $\begin{array}{l}0.2460^{* * *} \\
(0.0030)\end{array}$ \\
\hline Ln(GDP per capita) & $\begin{array}{c}-0.4773^{* * *} \\
(0.1563)\end{array}$ & $\begin{array}{c}-0.5599^{* * *} \\
(0.0274)\end{array}$ & $\begin{array}{l}1.0897^{* * *} \\
(0.2393)\end{array}$ & $\begin{array}{l}0.8055^{* * *} \\
(0.0469)\end{array}$ \\
\hline Life expectancy & $\begin{array}{c}-0.0203 \\
(0.0229)\end{array}$ & $\begin{array}{c}-0.0251^{* * *} \\
(0.0029)\end{array}$ & $\begin{array}{r}0.0742^{*} \\
(0.0376)\end{array}$ & $\begin{array}{l}0.0543^{* * *} \\
(0.0050)\end{array}$ \\
\hline Ln(population) & $\begin{array}{c}-0.5639^{* *} \\
(0.2201)\end{array}$ & $\begin{array}{c}-0.6281^{* * *} \\
(0.0307)\end{array}$ & $\begin{array}{c}1.0121 \\
(0.6094)\end{array}$ & $\begin{array}{l}0.7306^{* * *} \\
(0.0526)\end{array}$ \\
\hline Number of local substitutes & $\begin{array}{r}0.0060^{*} \\
(0.0032)\end{array}$ & $\begin{array}{l}0.0058^{* * *} \\
(0.0002)\end{array}$ & $\begin{array}{l}0.0133^{* * *} \\
(0.0039)\end{array}$ & $\begin{array}{l}0.0122^{* * *} \\
(0.0003)\end{array}$ \\
\hline Price index of ATC class & $\begin{array}{l}0.0175^{* * *} \\
(0.0039)\end{array}$ & $\begin{array}{l}0.0176^{* * *} \\
(0.0004)\end{array}$ & $\begin{array}{c}-0.0041 \\
(0.0030)\end{array}$ & $\begin{array}{c}-0.0042^{* * *} \\
(0.0007)\end{array}$ \\
\hline Log originator products in country, t- 1 & $\begin{array}{l}-0.0045 \\
(0.0155)\end{array}$ & $\begin{array}{c}-0.0080^{* * *} \\
(0.0020)\end{array}$ & $\begin{array}{l}0.1064^{* * *} \\
(0.0247)\end{array}$ & $\begin{array}{l}0.1079^{* * *} \\
(0.0034)\end{array}$ \\
\hline Intercept & $\begin{array}{c}1.6407 \\
(2.0668)\end{array}$ & $\begin{array}{l}2.1559^{* * *} \\
(0.2939)\end{array}$ & $\begin{array}{r}-7.0482^{*} \\
(3.9049) \\
\end{array}$ & $\begin{array}{c}-5.9182^{* * *} \\
(0.5040)\end{array}$ \\
\hline $\begin{array}{l}\mathrm{N} \\
\text { Adj. } R^{2}\end{array}$ & \multicolumn{4}{|c|}{620330} \\
\hline Fixed effects & \multicolumn{4}{|c|}{$\begin{array}{c}\text { Year } \\
\text { Drug } \\
\text { Country }\end{array}$} \\
\hline
\end{tabular}

$* \mathrm{p}<0.10,{ }^{* *} \mathrm{p}<0.05, * * * \mathrm{p}<.01$. Standard errors are clustered by country. The omitted income group is High income OECD. 
Figure 2: Patent protection and launch, by income group

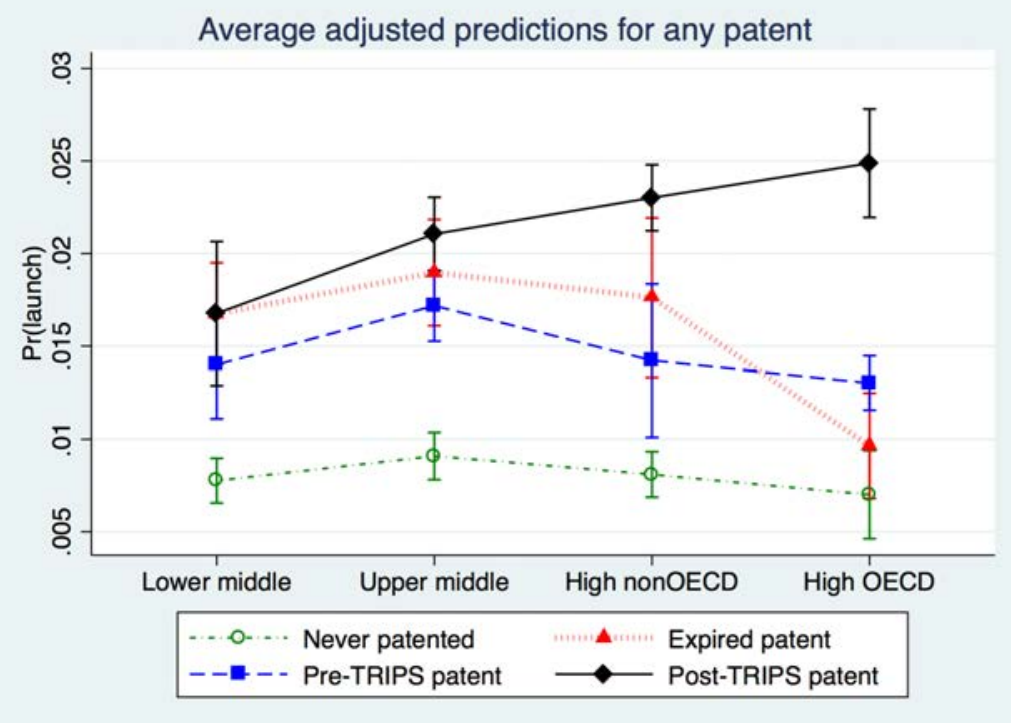

Figure 3: Patent protection and price, by income group

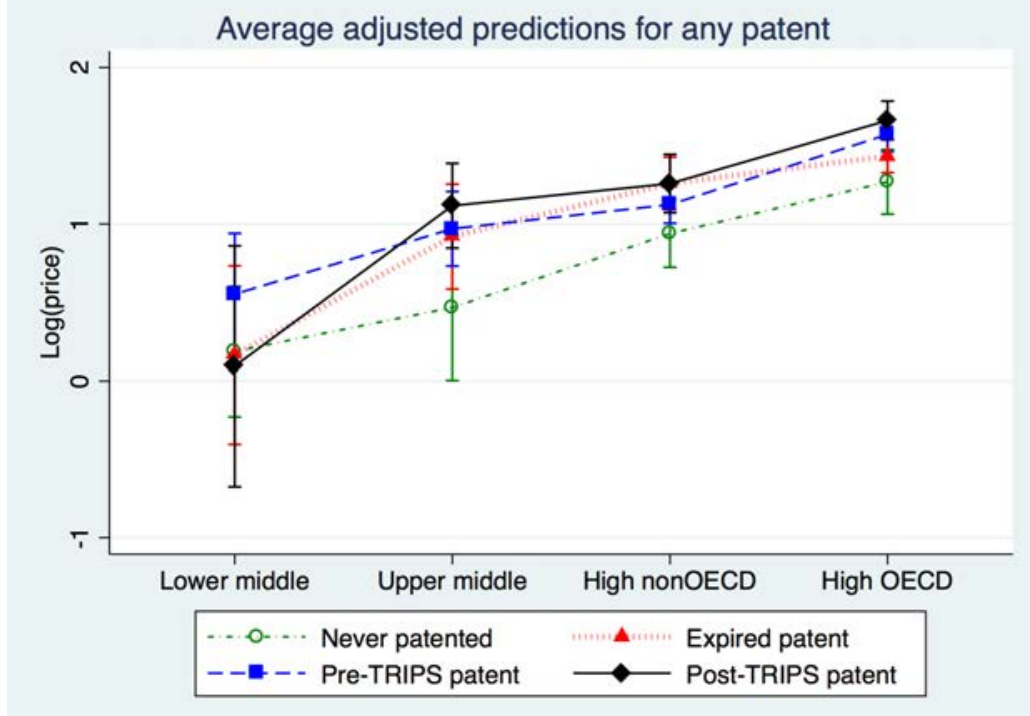


Figure 4: Patent protection and quantity, by income group

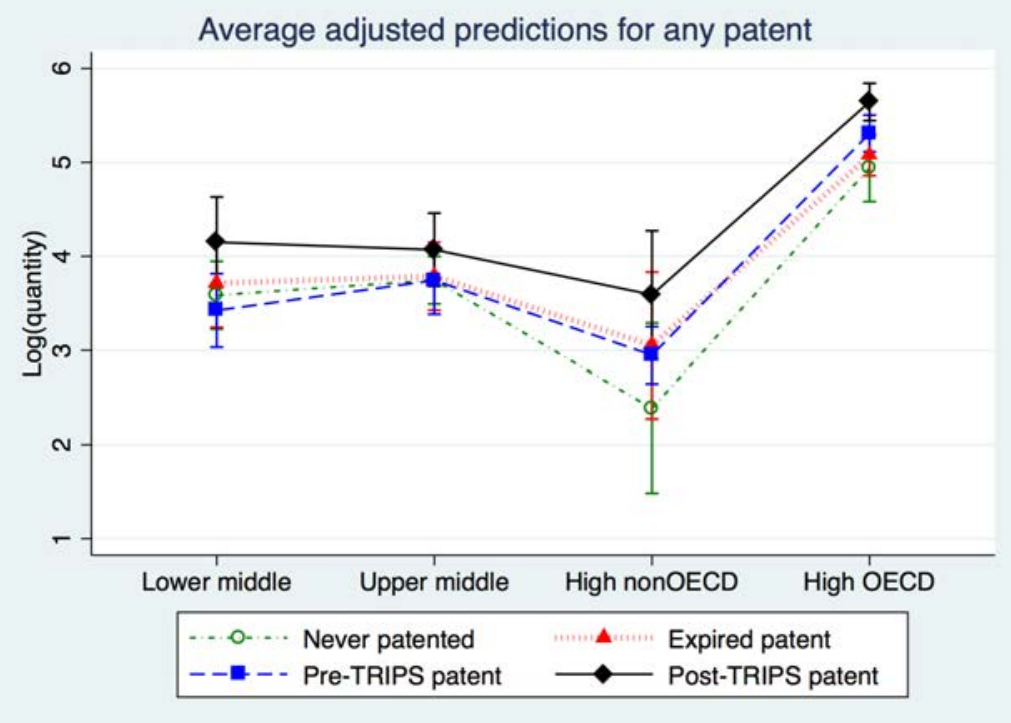

Figure 5: Patent protection and price, IV estimates

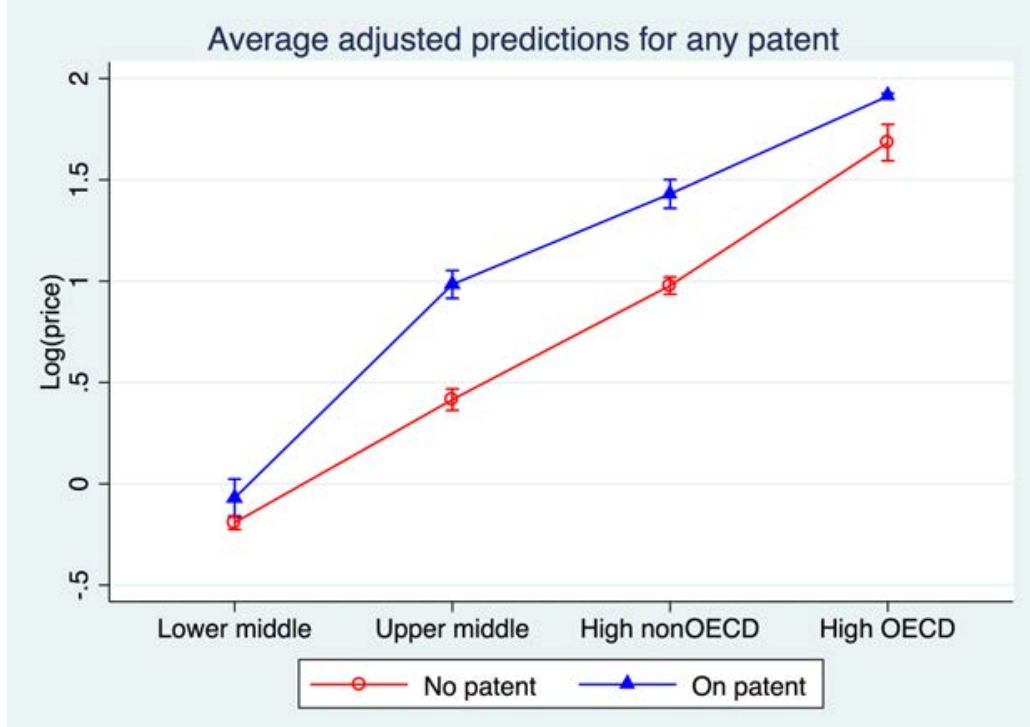


Figure 6: Patent protection and quantity, IV estimates

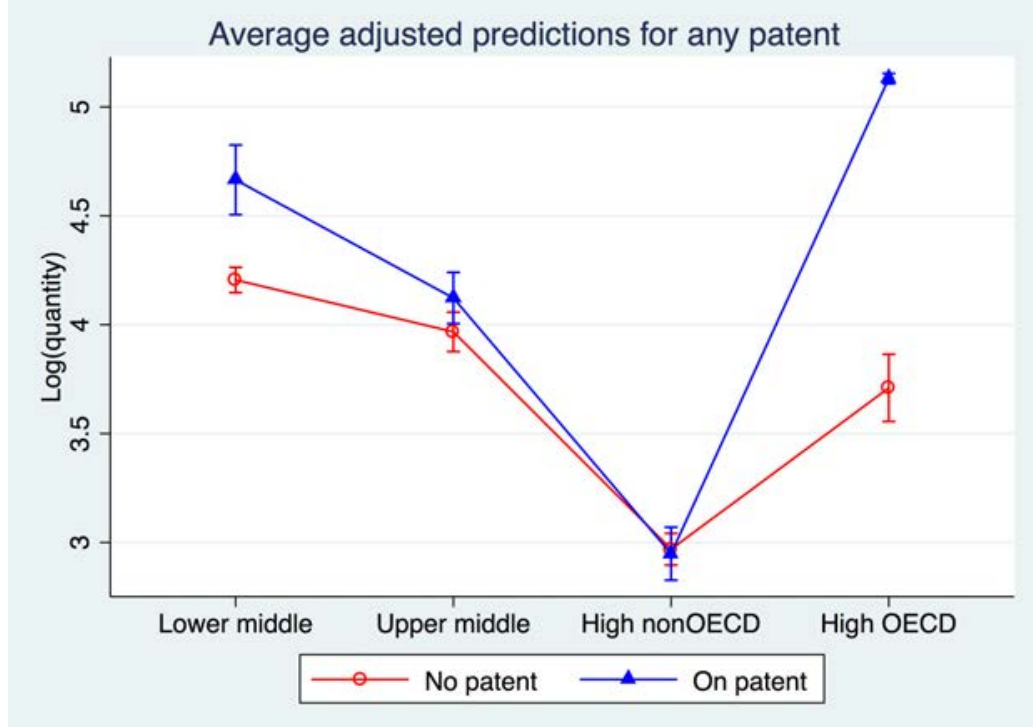

Figure 7: Patent protection and launch, by disease burden

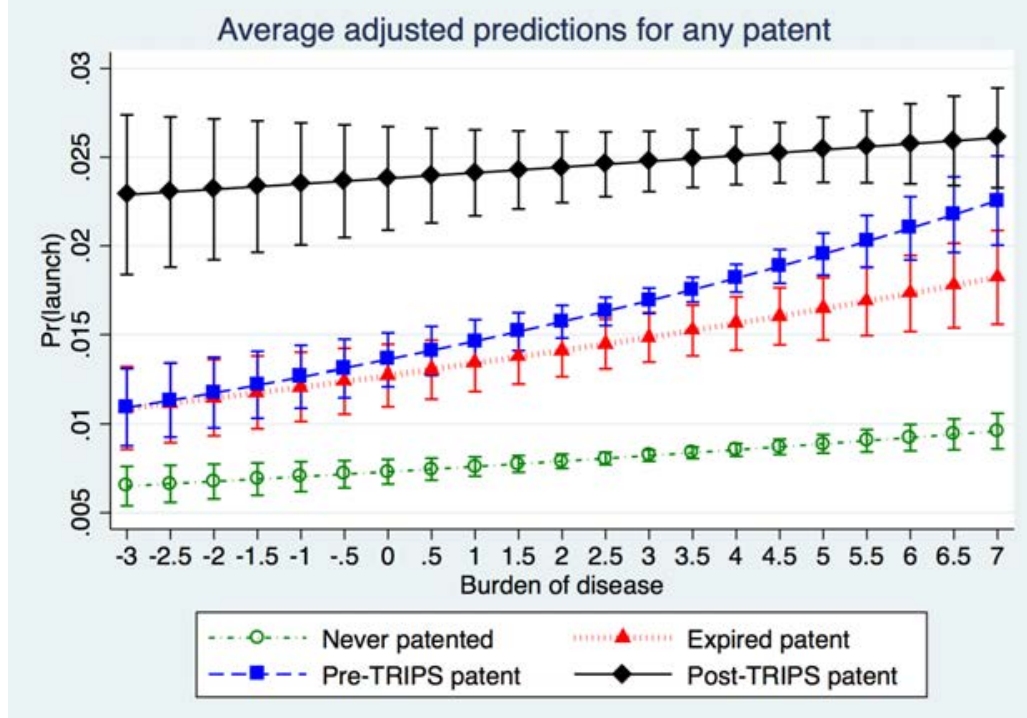


Figure 8: Patent protection and price, by disease burden

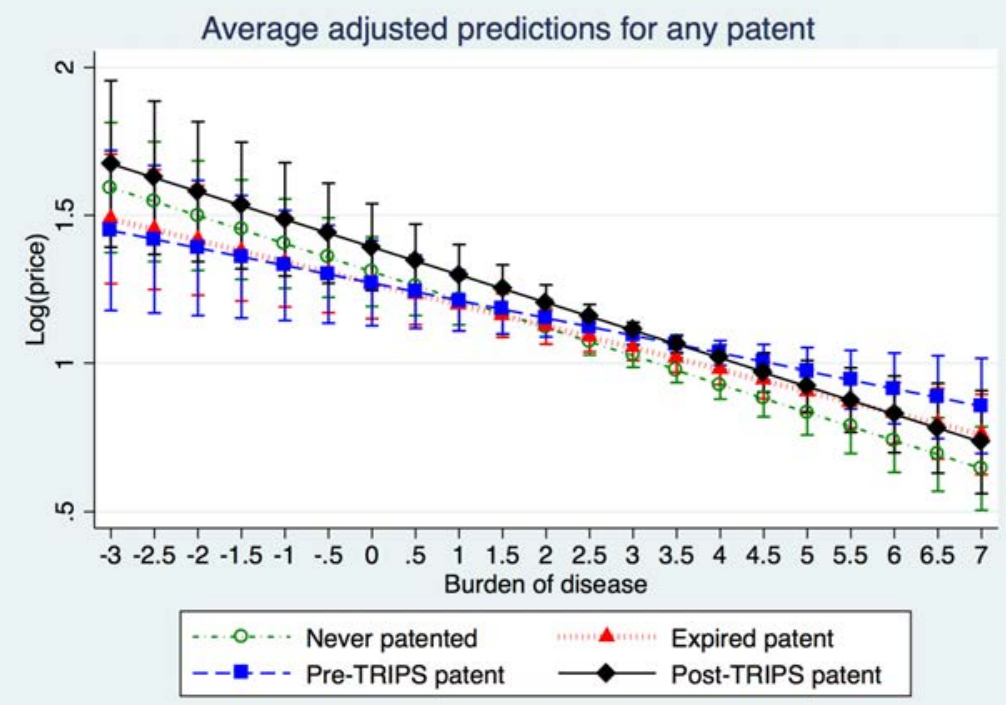

Figure 9: Patent protection and quantity, by disease burden

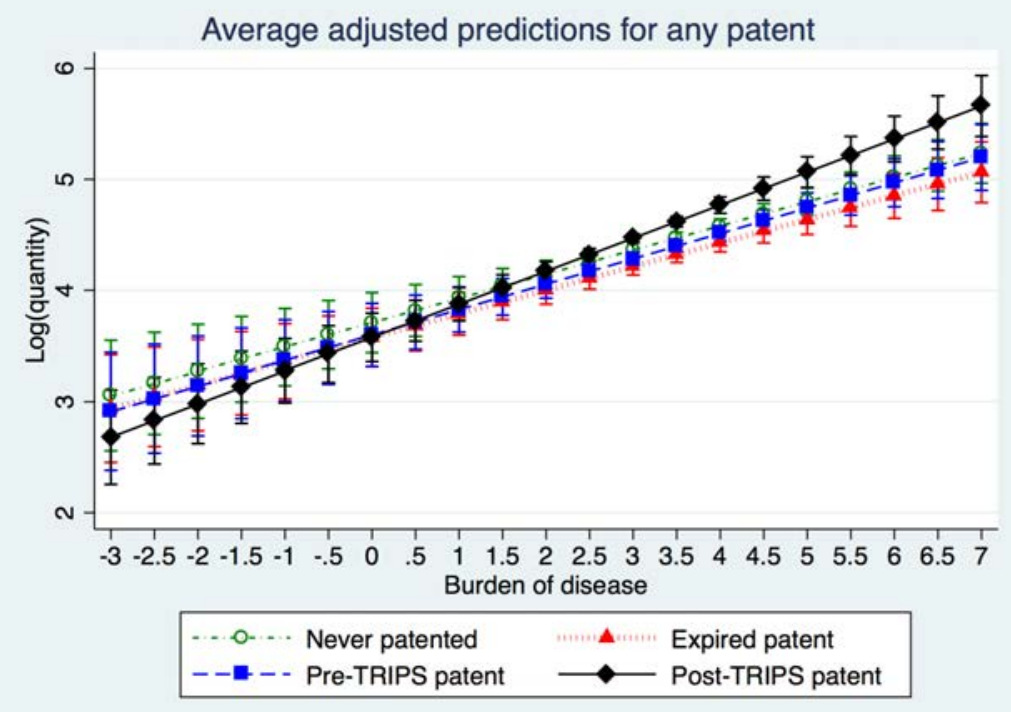




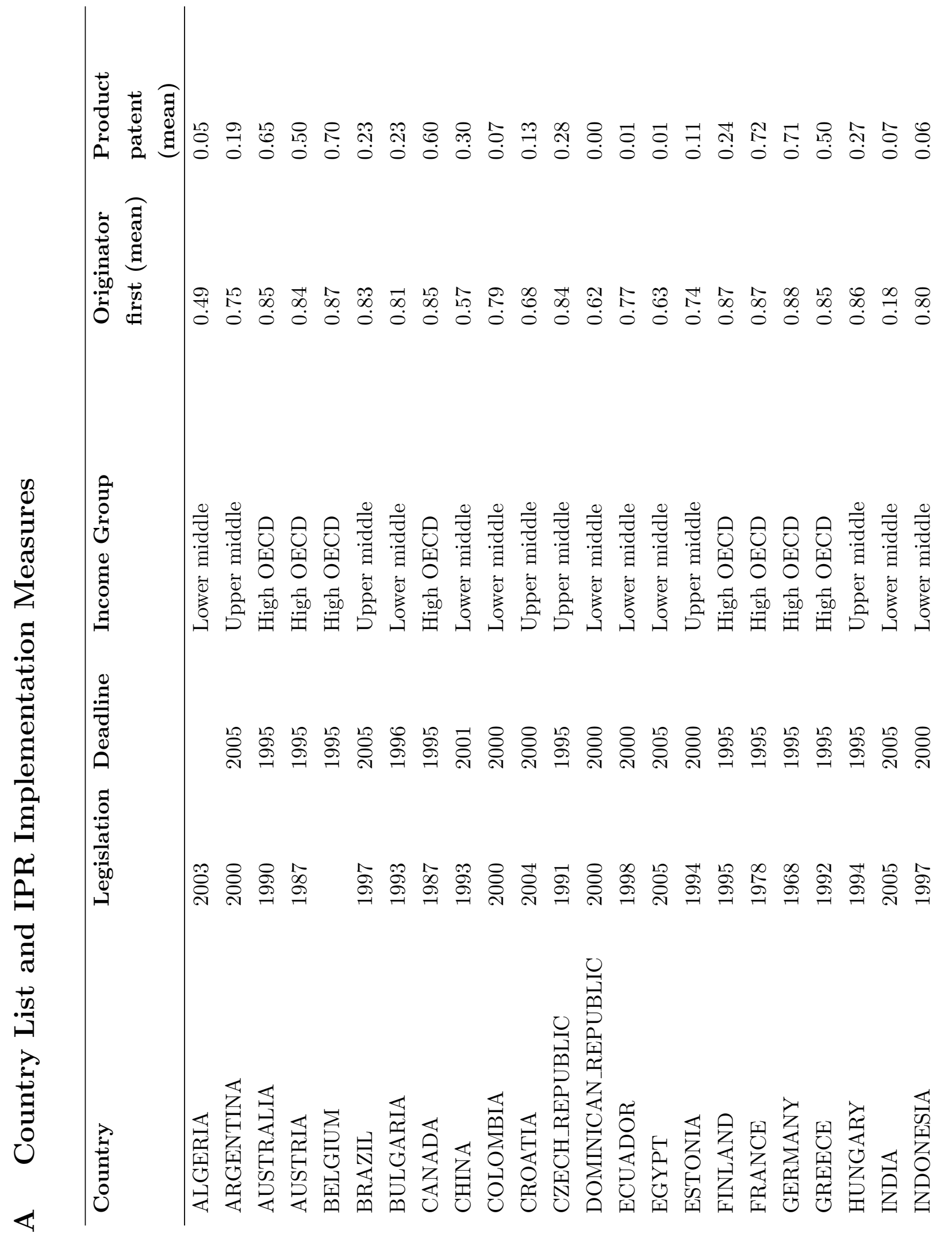




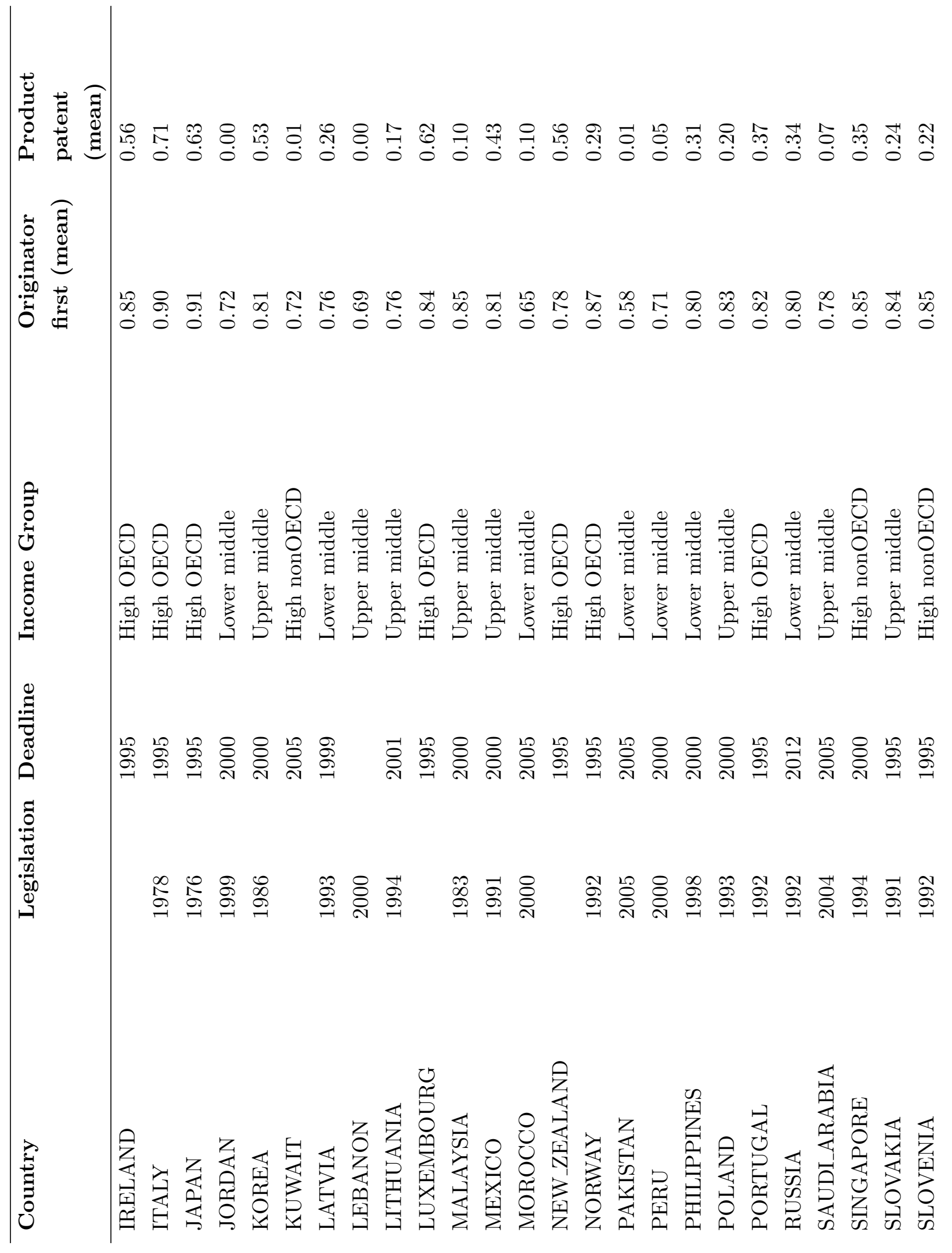




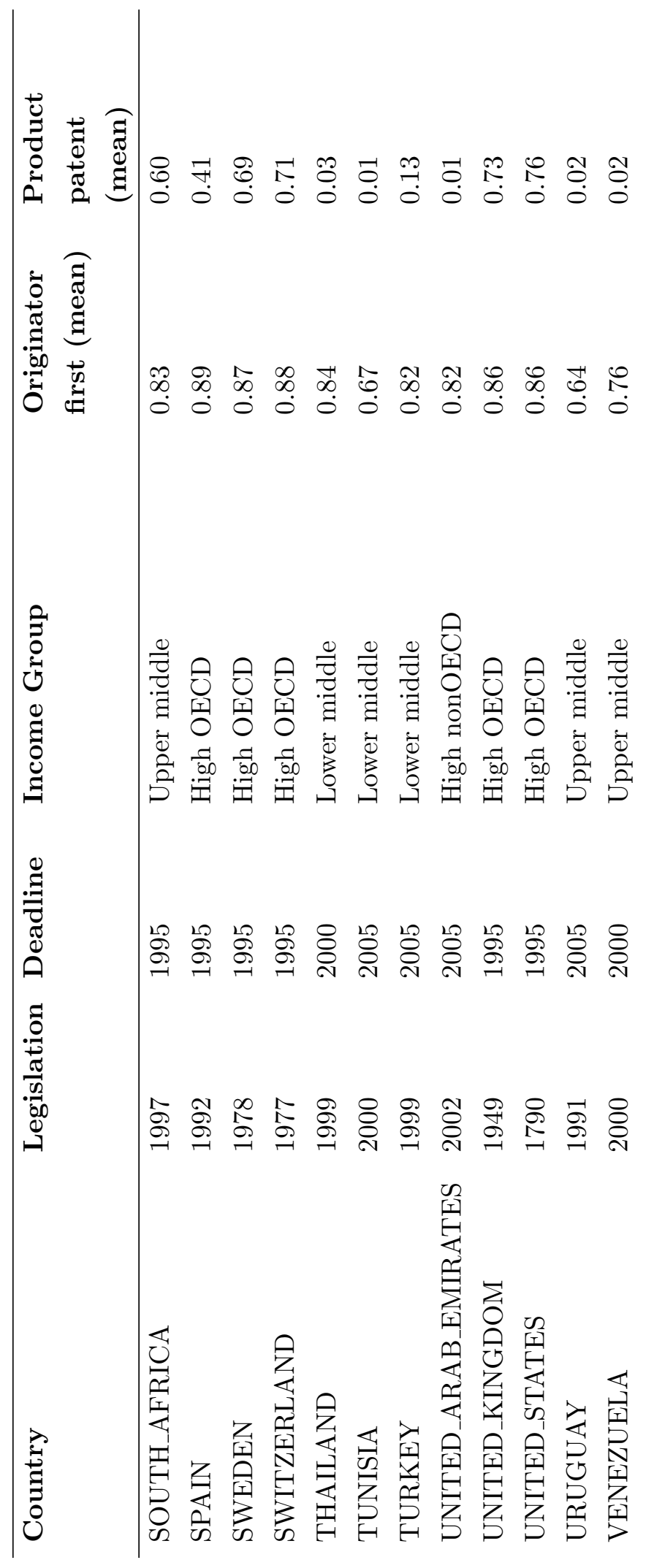

